\title{
Relation of completeness of reporting of health research to journals' endorsement of reporting guidelines: systematic review
}

\author{
(c) 1 (1) (9) OPEN ACCESS
}

\author{
Adrienne Stevens clinical research manager ${ }^{1}$, Larissa Shamseer $P h D$ candidate ${ }^{12}$, Erica Weinstein \\ medical student ${ }^{3}$, Fatemeh Yazdi senior clinical research associate ${ }^{1}$, Lucy Turner biostatistician ${ }^{1}$, \\ Justin Thielman MSc candidate ${ }^{1}$, Douglas G Altman professor ${ }^{4}$, Allison Hirst project manager ${ }^{5}$, \\ John Hoey retired professor ${ }^{6}$, Anita Palepu professor ${ }^{78}$, Kenneth F Schulz distinguished scientist ${ }^{9}$, \\ David Moher senior scientist ${ }^{12}$
}

${ }^{1}$ Centre for Practice-Changing Research, Ottawa Hospital Research Institute, Ottawa, ON, Canada, K1H 8L6; ${ }^{2}$ Department of Epidemiology and Community Medicine, University of Ottawa, K1H 8M5 Ottawa, Canada; ${ }^{3}$ Albert Einstein College of Medicine, Yeshiva University, Bronx, NY 10461, USA; ${ }^{4}$ Centre for Statistics in Medicine, University of Oxford, Oxford OX3 7LD, UK; ${ }^{5}$ Nuffield Department of Surgical Sciences, University of Oxford, Oxford OX3 9DU, UK; ${ }^{6}$ Population and Public Health Initiative, Queen's University, Kingston, ON, Canada, K7L 3N6; ${ }^{7}$ Centre for Health Evaluation and Outcome Sciences, St Paul's Hospital, Vancouver, BC, Canada, V6Z 1Y9 $;{ }^{8}$ Department of Medicine, University of British Columbia, Vancouver, BC, Canada, V5Z 1M9; ' International Clinical Sciences Support Center, FHI 360, Durham, NC 27713, USA

\begin{abstract}
Objective To assess whether the completeness of reporting of health research is related to journals' endorsement of reporting guidelines.

Design Systematic review.

Data sources Reporting guidelines from a published systematic review and the EQUATOR Network (October 2011). Studies assessing the completeness of reporting by using an included reporting guideline (termed "evaluations") (1990 to October 2011; addendum searches in January 2012) from searches of either Medline, Embase, and the Cochrane Methodology Register or Scopus, depending on reporting guideline name.

Study selection English language reporting guidelines that provided explicit guidance for reporting, described the guidance development process, and indicated use of a consensus development process were included. The CONSORT statement was excluded, as evaluations of adherence to CONSORT had previously been reviewed. English or French language evaluations of included reporting guidelines were eligible if they assessed the completeness of reporting of studies as a primary intent and those included studies enabled the comparisons of interest (that is, after versus before journal endorsement and/or endorsing versus non-endorsing journals).
\end{abstract}

Data extraction Potentially eligible evaluations of included guidelines were screened initially by title and abstract and then as full text reports. If eligibility was unclear, authors of evaluations were contacted; journals' websites were consulted for endorsement information where needed. The completeness of reporting of reporting guidelines was analyzed in relation to endorsement by item and, where consistent with the authors' analysis, a mean summed score.

Results 101 reporting guidelines were included. Of 15249 records retrieved from the search for evaluations, 26 evaluations that assessed completeness of reporting in relation to endorsement for nine reporting guidelines were identified. Of those, 13 evaluations assessing seven reporting guidelines (BMJ economic checklist, CONSORT for harms, PRISMA, QUOROM, STARD, STRICTA, and STROBE) could be analyzed. Reporting guideline items were assessed by few evaluations.

Conclusions The completeness of reporting of only nine of 101 health research reporting guidelines (excluding CONSORT) has been evaluated in relation to journals' endorsement. Items from seven reporting guidelines were quantitatively analyzed, by few evaluations each. Insufficient evidence exists to determine the relation between journals' endorsement of reporting guidelines and the completeness of reporting of published health research reports. Journal editors and researchers should consider collaborative prospectively designed, controlled studies to provide more robust evidence.

Systematic review registration Not registered; no known register currently accepts protocols for methodology systematic reviews. 


\section{Introduction}

Reporting of health research is, in general, bad. ${ }^{1-7}$ Complete and transparent reporting facilitates the use of research for a variety of stakeholders such as clinicians, patients, and policy decision makers who use research findings; researchers who wish to replicate findings or incorporate those findings in future research; systematic reviewers; and editors who publish health research. Reporting guidelines are tools that have been developed to improve the reporting of health research. They are intended to help people preparing or reviewing a specific type of research and may include a minimum set of items to be reported (often in the form of a checklist) and possibly also a flow diagram. ${ }^{8} 9$

An important role for editors is to ensure that research articles published in their journals are clear, complete, transparent, and as free as possible from bias. ${ }^{10}$ In an effort to uphold high standards, journal editors may feel the need to endorse multiple reporting guidelines without knowledge of their rigor or ability to improve reporting. The CONSORT statement is a well known reporting guideline that has been extensively evaluated. ${ }^{11-15} \mathrm{~A}$ 2012 systematic review indicated that, for some items of the CONSORT checklist, trials published in journals that endorse CONSORT were more completely reported than were trials published before the time of endorsement or in non-endorsing journals. ${ }^{16}{ }^{17}$ A similar systematic review of other reporting guidelines may provide editors and other end users with the information needed to help them decide which other guidelines to use or endorse.

Our objective was to assess whether the completeness of reporting of health research is related to journals' endorsement of reporting guidelines other than CONSORT by comparing the completeness of reporting in journals before and after endorsement of a reporting guideline and in endorsing journals compared with non-endorsing journals. For context, the box provides readers with definitions of terms used throughout this review.

\section{Methods}

Our methods are available in a previously published protocol. ${ }^{18}$ This systematic review is reported according to the PRISMA statement (appendix 1). ${ }^{19}$ Any changes in methods from those reported in the protocol are found in appendix 2.

\section{Identifying reporting guidelines}

We first searched for and selected reporting guidelines. We included reporting guidelines from Moher et al's 2011 systematic review, ${ }^{9}$ and we screened guidelines identified through the EQUATOR Network (October 2011; reflects content from PubMed searches to June 2011). We included English language reporting guidelines for health research if they provided explicit text to guide authors in reporting, described how the guidance was developed, and used a consensus process to develop the guideline.

After removing any duplicate results from the search yield, we uploaded records and full text reports to Distiller SR. Two people (AS and LS) independently screened reporting guidelines. Disagreements were resolved by consensus or a third person (DM).

\section{Identifying evaluations of reporting guidelines}

Many developers of reporting guidelines have devised acronyms for their guidelines for simplicity of naming (for example,
CONSORT, PRISMA, STARD). Some acronyms, however, refer to words with other meanings (for example, STROBE). For this reason, we used a dual approach to searching for evaluations of relevant reporting guidelines.

We searched for reporting guidelines with unique acronyms cited in bibliographic records in Ovid Medline (1990 to October 2011), Embase (1990 to 2011 week 41), and the Cochrane Methodology Register (2011, issue 4); we searched Scopus (October 2011) for evaluations of all other guidelines (that is, ones with alternate meanings or without an acronym). We did addendum searches in January 2012. Details are provided in appendix 3. In addition, we contacted the corresponding authors of reporting guidelines, scanned bibliographies of related systematic reviews, and consulted with members of our research team for other potential evaluations.

We included English or French language evaluations if they assessed the completeness of reporting as a primary intent and included studies enabling the comparisons of interest (after versus before journal endorsement and/or endorsing versus non-endorsing journals). Choice of language for inclusion was based on expertise within our research team; owing to budget constraints, we could not seek translations of potential evaluations in other languages.

After removing any duplicate results from the search yield, we uploaded records to Distiller SR. We first screened records by title and abstract (one person to include, two people to exclude a record) and then in two rounds for the full reports (two reviewers, independently) owing to the complexity of assessing screening criteria and using a team of reviewers. Disagreements were resolved by consensus or a third person. Where needed, we contacted authors of evaluations $(n=66)$ or journal editors $(n=48)$ for additional information. One person (from among a smaller working group of the team) processed evaluations with responses to queries to authors and journal editors and collated multiple reports for evaluations.

We first assessed each published study from within an included evaluation according to the journal in which it was published (fig $1 \Downarrow$ ). We collected information on endorsement from evaluations or journal websites. If the journal's "Instruction to authors" section (or similar) specifically listed the guideline, we considered the journal to be an "endorser."

\section{Data extraction and analysis}

For included reporting guidelines, one person extracted guidelines' characteristics. For evaluations of reporting guidelines, one person extracted characteristics of the evaluation and outcomes and did validity assessments; a second person verified $20 \%$ of the characteristics of studies and $100 \%$ of the remaining information. We contacted authors for completeness of reporting data for evaluations, where needed. Variables collected are reflected in the tables, figures, and appendices. As no methods exist for synthesizing validity assessments for methods reviews, we present information in tables and text for readers' interpretation.

Our primary outcome was completeness of reporting, defined as complete reporting of all elements within a guidance checklist item. As not all authors evaluated reporting guideline checklist items as stated in the original guideline publications, we excluded any items that were split into two or more separate items or reworded (leading to a change in meaning of the item).

Comparisons of interest were endorsing versus non-endorsing journals and after versus before endorsement. The first comparison functions as a cross sectional analysis, and years in which articles from endorsing journals were published depicted 


\section{Definitions related to evaluation of reporting guidelines in context of this systematic review}

Endorsement-Action taken by a journal to indicate its support for the use of one or more reporting guideline(s) by authors submitting research reports for consideration; typically achieved in a statement in a journal's "Instructions to authors"

Adherence-Action taken by an author to ensure that a manuscript is compliant with items (that is, reports all suggested items) recommended by the appropriate/relevant reporting guideline

Implementation-Action taken by journals to ensure that authors adhere to an endorsed reporting guideline and that published manuscripts are completely reported

Complete reporting-Pertains to the state of reporting of a study report and whether it is compliant with an appropriate reporting guideline

the years of comparison with articles from non-endorsing journals. We used the publication date of the reporting guideline as a proxy if the actual date of endorsement was not known. For the second comparison, we included before and after studies from the same journal only if a specific date of endorsement was known. We also examined the publication years of included studies to ensure that years were close enough within a given arm for reasonable comparison. As a result, not all studies included in the evaluations were included in our analysis. We analyzed the completeness of reporting in relation to journals' endorsement of guidelines by item (number of studies within an evaluation completely reporting a given reporting item) and by mean summed score (we calculated a sum of completely reported guideline items for each study included in an evaluation and compared the mean of those sums across studies between comparison groups); we used a mean summed score only when evaluations also analyzed in this manner. We used risk ratios, standardized mean differences, and mean differences with associated $99 \%$ confidence intervals for analyses, as calculated using Review Manager software..$^{20}$ In most cases, we reworked authors' data to form our comparison groups of interest for the analysis.

Where possible, we used a random effects model meta-analysis to do a quantitative synthesis across evaluations for a given checklist item or for the mean summed score. We entered evaluations into Review Manager as the "studies," whereas studies included within a given evaluation formed the unit of analysis, just as the number of patients would normally be entered. We entered the pooled effect estimate and confidence interval values from Review Manager for each checklist into Comprehensive Meta-Analysis to create summary plots depicting a "snapshot" view for each reporting guideline. ${ }^{21}$

Secondary outcomes were methodological quality and unwanted effects of using a guideline, as reported in evaluations. We present data for these outcomes in narrative form.

\section{Results}

\section{Literature search results Reporting guidelines}

Eighty one reporting guidelines from Moher et al's 2011 systematic review ${ }^{9}$ and 23 of 98 reporting guidelines identified by the EQUATOR Network were initially eligible for inclusion (fig $2 \Downarrow$ ). After removal of the CONSORT guidelines, we included a total of 101 reporting guidelines. ${ }^{19}$ 22-121

\section{Evaluations of reporting guidelines}

Our literature search included evaluations of the CONSORT guidelines, but we excluded those during the screening process. We located 17225 records through bibliographic databases and an additional 49 records from other sources (bibliographies, web search for full text reports of conference abstracts, and articles suggested by authors of reporting guidelines and members of the research team). After removing companion (known multiple publications) and duplicate reports, we screened a total of 15249 title and abstract records. Of those, 1153 were eligible for full text review. After two rounds of full text screening, contacting authors, and seeking journal endorsement information, we included a total of 26 evaluations (fig $3 \Downarrow$ ). ${ }^{122-147}$ A list of potential evaluations written in languages other than English or French is provided in appendix 4.

Nine reporting guidelines were assessed among the 26 included evaluations: STARD 2003 for studies of diagnostic accuracy $(\mathrm{n}=8),{ }^{131-138}$ CONSORT extension for harms 2004 $(\mathrm{n}=5),{ }^{124-126} 141{ }^{142}$ PRISMA 2009 for systematic reviews and meta-analyses $(\mathrm{n}=3),{ }^{143-145}$ QUOROM 1999 for meta-analyses of randomized trials $(\mathrm{n}=3),{ }^{128-130}$ BMJ economics checklist 1996 ( $n=2$ evaluations), ${ }^{122}{ }^{123}$ STROBE 2007 for observational studies in epidemiology $(n=2),{ }^{140}{ }^{147}$ CONSORT extension for journal and conference abstracts $2008(\mathrm{n}=1),{ }^{146}$ CONSORT extension for herbal interventions $2006(\mathrm{n}=1),{ }^{127}$ and STRICTA 2002 for controlled trials of acupuncture $(n=1){ }^{139}$

\section{Characteristics of included studies}

\section{Reporting guidelines}

Appendix 5 descriptively summarizes included reporting guidelines according to the focus of the guideline and the content area the guideline covers. Among included guidelines were those covering general health research reports; animal, pre-clinical, and other basic science reports; a variety of health research designs and types of health research; and a variety of content areas.

\section{Evaluations of reporting guidelines}

Tables $1 \Downarrow$ and $2 \Downarrow$ show characteristics of the included evaluations. The most frequent content focuses of evaluations were diagnostic studies $(7 / 26 ; 27 \%)$, drug therapies $(6 / 26 ; 23 \%)$, and unspecified $(5 / 26 ; 19 \%)$; evaluations spanned a variety of biomedical areas. Funding was most frequently either not reported $(13 / 26 ; 50 \%)$ or provided by a government agency $(7 / 26 ; 27 \%)$, and the role of the funder in the conduct of the evaluation was not reported in most evaluations (22/26; 85\%). Two thirds of the evaluations provided a statement regarding competing interests or declared authors' source(s) of support (17/26; 65\%). Corresponding authors of evaluations were located in nine countries; $37 \%(10 / 27)$ of corresponding authors were in the United Kingdom.

For each included evaluation, tables $3 \Downarrow$ and $4 \Downarrow$ show the number of studies relevant to our assessments, their year(s) of publication, and the number of journals publishing the relevant studies. Tables $5 \Downarrow$ and $6 \Downarrow$ present information on the extent of journals' endorsement and whether the date of endorsement was provided by evaluation authors, journal websites, or editors.

\section{Validity assessment}

Tables $3 \Downarrow$ and $4 \Downarrow$ show validity assessments for the comparisons; supports for those judgments are in appendix 6 . Table $3 \Downarrow$ provides information on evaluations for the endorsing versus 
non-endorsing journal comparison; table $4 \Downarrow$ includes information for those evaluations that included studies pertaining to the after versus before endorsement comparison. More than half (15/26; $58 \%$ ) of the evaluations used at least two people to assess the completeness of reporting. Selective reporting does not seem to be a problem, as most evaluations $(20 / 26 ; 77 \%)$ assessed the number of reporting items as stipulated in the methods section. A comprehensive search strategy for locating relevant studies was not reported for most evaluations $(5 / 26 ; 19 \%)$; an evaluation with the intention of evaluating reports from specific journals in a specified time period would have been deemed adequately comprehensive. When comparing endorsing journals with non-endorsing journals, half of the evaluations $(14 / 25 ; 56 \%)$ had a similar number of studies per journal in the comparison groups; when comparing journals after and before endorsement, less than half of the evaluations $(4 / 10 ; 40 \%)$ were balanced for the number of studies per journal in the comparison groups to account for a potential "clustering" problem. When comparing journals after and before endorsement, most evaluations (7/10; $70 \%$ ) had studies in the "before" arm that were published before the reporting guideline was published, possibly confounding the evaluations.

\section{Relation between journals' endorsement of guidelines and completeness of reporting}

Of the 26 included evaluations, we were able to quantitatively analyze 13; we did not have access to the raw data for the remaining evaluations. The CONSORT extensions for herbal interventions and journal/conference abstracts reporting guidelines were covered by one evaluation each, but raw data were not available for our analysis. Because of the few evaluations with available data, we were unable to do pre-planned subgroup and sensitivity analyses and assessments of funnel plot asymmetry. ${ }^{18}$ Data described below pertain to overall analyses of checklist items by guideline; individual analyses for each checklist item and mean summed score are provided in appendix 7 .

\section{Endorsing versus non-endorsing journals}

Analyzed by checklist item, the CONSORT extension for harms (10 items), PRISMA (27 items), STARD (25 items), and STROBE (34 items) reporting guidelines were evaluated on all items; a subset of items was analyzed for the BMJ economics checklist (19/35 items) and STRICTA (18/20 items) guidelines. Most items were assessed by only one evaluation; STARD items were assessed by two to four evaluations and PRISMA by mostly two to three evaluations (figures $4 \Downarrow, 5 \Downarrow, 6 \Downarrow, 7 \Downarrow, 8 \Downarrow$, and $9 \Downarrow$ ). Relatively few relevant studies were included in the assessments (median 85, interquartile range 47-143, studies). Across guidelines, almost all items were statistically non-significant for completeness of reporting in relation to journal endorsement (figures $4 \Downarrow, 5 \Downarrow, 6 \Downarrow, 7 \Downarrow, 8 \Downarrow$, and $9 \Downarrow$ ).

The CONSORT extension for harms, PRISMA, STARD, STRICTA, and STROBE were each analyzed by mean summed score, for which some evaluations used all items and others used a subset of items (table $7 \Downarrow$ ). Guidelines were assessed by a range of one to three evaluations. Relatively few relevant studies were included in the assessments (median 102, interquartile range 88-143, studies). Analyses for completeness of reporting in relation to journal endorsement for mean summed scores were statistically non-significant for all except PRISMA (table $7 \Downarrow$ ).

\section{After versus before journal endorsement}

Analyzed by checklist item, STROBE (34 items) and PRISMA (27 items) were the only reporting guidelines with all items evaluated; the QUOROM (1/17 items), STARD (1/25 items), and STRICTA (17/20 items) guidelines were evaluated for a subset of items. All were assessed by one evaluation each with the exception of PRISMA. Relatively few relevant studies were included in the assessments (median 20, interquartile range 19-64, studies; figures $10 \Downarrow, 11 \Downarrow, 12 \Downarrow, 13 \Downarrow$, and $14 \Downarrow$ ). Analyses for completeness of reporting in relation to endorsement were statistically non-significant for each checklist item.

PRISMA (all checklist items), STRICTA (item subset), and STROBE (all checklist items) reporting guidelines were analyzed by a mean summed score and by one or two evaluations each. Relatively few relevant studies were included in the assessments (median 20, interquartile range 18-50, studies), and analyses for completeness of reporting in relation to endorsement for mean summed scores were statistically non-significant (table $8 \Downarrow$ ).

\section{Assessment of study methodological quality within evaluations}

Nine of 26 evaluations assessed the methodological quality of included studies (table $9 \Downarrow$ ): one economics evaluation, ${ }^{122}$ one evaluation assessing randomized trials of herbal medicines, ${ }^{127}$ five systematic review evaluations, ${ }^{129}{ }^{130}{ }^{143-145}$ and two evaluations assessing diagnostic studies. ${ }^{131} 137$ Relatively few studies per evaluation were included in the assessments. The three more recently published systematic review evaluations used AMSTAR, whereas the older two evaluations used the Oxman and Guyatt index. The two diagnostic evaluations used separate, non-overlapping criteria. Given the different methodological areas and tools represented by the evaluations, a meaningful synthesis statement was not possible.

\section{Unwanted effects of reporting guideline use}

None of the included evaluations reported on unwanted effects of reporting guideline use.

\section{Discussion}

We reviewed the evidence on whether endorsement of reporting guidelines by journals is associated with more complete reporting of research. Although we identified a large number of reporting guidelines, very few evaluations of those reporting guidelines were located and provided information to enable an examination with respect to endorsement.

\section{Strengths and weaknesses of systematic review}

This is the first systematic review to comprehensively review a broad range of reporting guidelines. We sourced these reporting guidelines from the EQUATOR Network and another systematic review characterizing known, high quality guidelines. We gave careful consideration to the parameters required to enable our comparisons of interest and made a considerable effort to locate evaluations, including the re-analysis of others' data.

As exemplified by the volume of literature we had to screen, searching is complex with methods reviews. No search filters or established bibliographic database controlled vocabulary terms exist, especially for reporting guidelines. For many methods reviews, the particular studies of interest are often embedded in other studies. The time consuming task of 
screening leads to a very low yield. Although systematic reviews are customarily current with the literature on publication, all such evidence pertains to comparative effectiveness reviews and not to methods reviews, such as ours. An updated search would yield more than 6000 records for us to screen with likely only a few relevant studies. We were aware of additional evaluations that have been published since the date of our literature search, and we have added these into our review. These additional studies have not led to a change in our conclusions. Other recently published articles did not meet our criteria. ${ }^{148-150}$ We do not believe that an updated search would identify sufficient additional studies to change our results.

We limited our inclusion to evaluations written in English or French. This may be a limitation of our work, but we are unclear as to how many evaluations might exist in other languages given that few reporting guidelines are translated into other languages.

We did not include the main CONSORT reporting guideline here, and this decision was made after the initial protocol was written. The volume of evaluations for CONSORT is so large that we felt that detailed analysis would have overwhelmed the evidence from other reporting guidelines; furthermore, a systematic review solely evaluating the effect of CONSORT is available as recently as $2012 .{ }^{16}{ }^{17}$

\section{Comparison with other reviews}

The findings from the 2012 CONSORT systematic review show that, for some CONSORT checklist items, trials published in journals that endorse CONSORT were more completely reported than were trials published before the time of endorsement or in non-endorsing journals. ${ }^{16}{ }^{17}$ CONSORT is by far the most extensively evaluated reporting guideline, in contrast to the reporting guidelines covered in this review. At least one other review evaluating CONSORT for harms has been published. ${ }^{151}$ We examined this review, and studies included in that review but not in ours would not have met our eligibility criteria.

\section{Meaning of review: explanations and implications}

Although reporting guidelines might have sufficient face validity to convince some editors to endorse them, we found little evidence to guide this policy. This is in stark contrast, for example, to the evidence required to introduce a new drug in the marketplace. Here, empirical evidence in the form of pivotal randomized trials would be required. Although reporting guidelines are not drugs, they have become increasingly popular, their trajectory continues to increase very quickly, and journal editors and others are making policy decisions about encouraging their use in hundreds if not thousands of journals. Evidence relating to CONSORT, STARD, MOOSE, QUOROM, and STROBE indicates that no standard way exists in which journals endorse reporting guidelines. ${ }^{152-155}$ Furthermore, other than including recommendations in their "Instructions to authors," little is known about what else is done by individual journals to ensure adherence to reporting guidelines. This is an question of fidelity; the effect of endorsement is therefore plagued by different, and not well documented, processes as to the "strength" of endorsement. For example, some journals require a completed reporting guideline checklist as part of the manuscript submission, whereas others only suggest the use of reporting guidelines to facilitate writing of manuscripts. In both instances, whether or how journals check that authors adhere to journals' recommendations/requirements is not known. One strategy would be to encourage peer reviewers to check adherence to the relevant reporting guideline. A 2012 survey of journals' instructions to peer reviewers shows that reference to or recommendations to use reporting guidelines during peer review was rare (19 of 116 journals assessed). ${ }^{156}$ When mentioned, instructions on how to use reporting guidelines during peer review were entirely absent; most journals pointed to CONSORT but few other reporting guidelines. Specifically, surveys of journals' instructions to authors with respect to endorsement of CONSORT show that guidance is inconsistent and ambiguous and does not provide authors with a strong indication of what is expected of them in terms of using CONSORT during the manuscript submission process. ${ }^{152} 153157$ Evidence from this review and a similar CONSORT systematic review suggest much room for improvement in how journals seek to achieve adherence to reporting guidelines. ${ }^{16}{ }^{17}$ Developers of reporting guidelines and editors could work together and agree on the optimal way to endorse and implement reporting guidelines across journals (bringing some standardization to the implementation process).

A fundamental outcome used by evaluators was the completeness of reporting according to items from the reporting guideline. Ideally, this means that all concepts were reported about a particular reporting guideline checklist item. For example, in the STARD statement, one checklist item covers the "technical specifications of material and methods involved using how and when measurements were taken, and/or cite references for the index tests and reference standard." For this item, some evaluations separated and tracked reporting information for the index test separately from the reference standard. We had to exclude nine evaluations that did not have any original, unmodified checklist items (that is, guidance items that were split into subcomponents or written with modified interpretation). Furthermore, as noted in tables $1 \Downarrow$ and $2 \Downarrow$, more than half of the included evaluations applied modifications to one or more items of the original guidance, negating the inclusion of those items in our analyses.

Evaluating the completeness of reporting of reporting guidelines in relation to journals' endorsement might seem straightforward. However, in reality, it is complex. One problem in approaching our analysis is that only three evaluations considered endorsement as the "intervention" of interest, of which two could be included in our quantitative analysis. As a result, we had to rework authors' data to facilitate the comparisons of interest and track down journals' endorsement information, requiring considerable time and effort. Evaluators of reporting guidelines, in general, have not considered endorsement as an "intervention" that has the potential to affect the completeness of reporting. Although evaluations in this review do not provide conclusive evidence, the CONSORT review provides some evidence that simple endorsement of reporting guidelines has the potential to affect the completeness of reporting. ${ }^{16} 17$

One design used in the literature is the comparison of complete reporting before and after the publication of a reporting guideline. In thinking about this as an intervention and then considering endorsement, endorsement would likely serve as a "stronger" intervention given the need for manuscripts to adhere to a journal's "Instruction to authors" and subsequent editorial process. However, as mentioned above, the strength of endorsement is crucial and varies across journals. Thus, although not ideal, a journal's statement about endorsement of a guideline is the best available proxy indicator of a journal's policy and perhaps authors' behavior around use of reporting guidelines. In terms of experimental designs, randomizing journals to endorse a reporting guideline or continue with usual editorial policy would be difficult, if not impossible. One method of intervening and evaluating can be with peer reviewers, as 
mentioned above. To our knowledge, at least one randomized trial by Cobo et al in 2011 has examined the use of reporting guidelines in the peer review process within a single journal that did not endorse any reporting guidelines; it found that manuscripts reviewed using reporting guidelines were of better quality than those that did not use reporting guidelines. ${ }^{158}$ Although these findings are applicable only to a single journal, more trials like this can provide journals with their own evidence on completeness of reporting and better inform editors as to whether efforts on endorsement and, further, implementation, are having their intended effects.

Beyond simple publication of a guideline, little effort is dedicated to knowledge translation (implementation) activities. As defined by the Canadian Institutes of Health Research, the crux of knowledge translation is that it is a move beyond the simple dissemination of knowledge into the actual use/implementation of knowledge. ${ }^{159}$ The EQUATOR Network has gone some way in providing a collated home and network of reporting guidelines and resources. However, knowledge producers/guideline developers are responsible for ensuring appropriate and widespread use of a particular guideline by knowledge users. Developers and interested researchers may wish to think about studying the behaviors of target users (for example, prospective journal authors) and developing, carrying out, and evaluating strategies that have the potential to affect behavior change around guideline use, similar to ongoing work in implementation of clinical research. ${ }^{160} 161$

\section{Future research}

Future evaluations of reporting guidelines should assess unmodified reporting items. Non-experimental designs on the basis of journal endorsement status can help to supplement the evidence base. However, researchers in this area, such as guideline developers, should consider carrying out prospectively designed, controlled studies, like the study by Cobo et al, ${ }^{158}$ in the context of the journal's editorial process to provide more robust evidence.

\section{Conclusions}

The completeness of reporting of only nine of 101 rigorously developed reporting guidelines has been evaluated in relation to journal endorsement status. Items from seven reporting guidelines were quantitatively analyzed by few evaluations each. Insufficient evidence exists to determine the relation between journals' endorsement of reporting guidelines and the completeness of reporting in published health research reports. Future evaluations of reporting guidelines can take the form of comparisons based on journal endorsement status, but researchers should consider prospectively designed, controlled studies conducted in the context of the journal's editorial process.

We thank Shona Kirtley for information regarding the EQUATOR network search strategy for reporting guidelines, Andra Morrison for peer reviewing the search strategies developed for this review, Becky Skidmore for designing and conducting literature searches, Mary Gauthier and Sophia Tsouros for assisting with screening, Kavita Singh for assisting with screening and data extraction, Misty Pratt for assisting with screening and data extraction and verification, Raymond Daniel for article acquisition and management of bibliographic records within Reference Manager 12 and Distiller SR, Hadeel AIYacoob for assisting with verification of data extraction and analyses, Iveta Simera for contributions to the design of the project and feedback on the manuscript, and the authors of reporting guidelines and journal editors who kindly responded to our requests for information. We thank Stefania Boccia, Nikola Panic, Julien Peron, Benoit You, and other authors of evaluations who responded to our queries and provided raw data for our analyses.

Contributors: AS, LS, DM, DGA, LT, AH, JP, AP, and KFS contributed to the conception and design of this review via the published protocol. All authors contributed to the screening, data extraction, analysis, or data interpretation phases of the review. AS and DM drafted the review, and all remaining authors revised it critically for important intellectual content. All authors approved the final manuscript. DM is the guarantor. Funding: This work was supported by a grant from the Canadian Institutes of Health Research (funding research number KSD-111750). The Canadian Institutes of Health Research had no role in the design, data collection, analysis, or interpretation of the data; in the writing of the report; or in the decision to submit this work for publication. DGA is supported by Cancer Research UK, DM by a University of Ottawa research chair, and KFS by FHI360. All researchers are independent from their relevant funding agencies. DGA, DM, and KFS are executive members of the EQUATOR network; AH served as an EQUATOR staff member during this project. The EQUATOR Network is funded by the National Health Service National Library of Health, National Health Service National Institute for Health Research, National Health Service National Knowledge service, United Kingdom Medical Research Council, Scottish Chief Scientist Office, and Pan American Health Organization. Competing interests: All authors have completed the ICMJE uniform disclosure form at www.icmje.org/coi_disclosure.pdf (available on request from the corresponding author) and declare: all authors maintained their independence from the agency that funded this work; no financial relationships with any organizations that might have an interest in the submitted work in the previous three years; no other relationships or activities that could appear to have influenced the submitted work.

Ethical approval: This systematic review did not require ethics approval in Canada.

Data sharing: Datasets are available on request from the corresponding author.

Transparency: The lead author (guarantor) affirms that the manuscript is an honest, accurate, and transparent account of the study being reported; that no important aspects of the study have been omitted; and that any discrepancies from the study as planned (and, if relevant, registered) have been explained.

1 Chan AW, Altman DG. Epidemiology and reporting of randomised trials published in PubMed journals. Lancet 2005;365:1159-62.

2 Chan S, Bhandari M. The quality of reporting of orthopaedic randomized trials with use of a checklist for nonpharmacological therapies. J Bone Joint Surg Am 2007;89:1970-8.

3 Moher D, Tetzlaff J, Tricco AC, Sampson M, Altman DG. Epidemiology and reporting characteristics of systematic reviews. PLoS Med 2007;4:447-55.

4 Smith BA, Lee HJ, Lee JH, Choi M, Jones DE, Bausell RB, et al. Quality of reporting randomized controlled trials (RCTs) in the nursing literature: application of the consolidated standards of reporting trials (CONSORT). Nurs Outlook 2008;56(1):31-7.

5 Yesupriya A, Evangelou E, Kavvoura FK, Patsopoulos NA, Clyne M, Walsh MC, et al. Reporting of Human Genome Epidemiology (HuGE) association studies: an empirical assessment. BMC Med Res Methodol 2008;8.

6 Zhang D, Yin P, Freemantle N, Jordan R, Zhong N, Cheng KK. An assessment of the quality of randomised controlled trials conducted in China. Trials 2008;9:22.

7 Glasziou P, Altman DG, Bossuyt P, Boutron I, Clarke M, Julious S, et al. Reducing waste from incomplete or unusable reports of biomedical research. Lancet 2014;383:267-76.

8 Moher D, Schulz KF, Simera I, Altman DG. Guidance for developers of health research reporting guidelines. PLoS Med 2010;7(2).

9 Moher D, Weeks L, Ocampo M, Seely D, Sampson M, Altman DG, et al. Describing reporting guidelines for health research: a systematic review. J Clin Epidemiol 2011;64:718-42

10 World Medical Association. Declaration of Helsinki: ethical principles for medical research involving human subjects. JAMA 2013;310:2191-4.

11 Begg C, Cho M, Eastwood S, Horton R, Moher D, Olkin I, et al. Improving the quality of reporting of randomized controlled trials: the CONSORT statement. JAMA 1996;276:637-9.

12 Moher D, Schulz KF, Altman DG, Lepage L. The CONSORT statement: revised recommendations for improving the quality of reports of parallel group randomized trials. BMC Med Res Methodol 2001;1:1-7.

13 Altman DG, Schulz KF, Moher D, Egger M, Davidoff F, Elbourne D, et al. The revised CONSORT statement for reporting randomized trials: explanation and elaboration. Ann Intern Med 2001;134:663-94.

14 Schulz KF, Altman DG, Moher D, for the CONSORT Group. CONSORT 2010 statement: updated guidelines for reporting parallel group randomised trials. BMJ 2010;340:c332. 


\section{What is already known on this topic}

Complete and transparent reporting of research, which is often inadequate and incomplete, enables readers to assess the internal validity and applicability of findings

The completeness of reporting of the CONSORT guideline in relation to endorsement by journals has been evaluated and was shown to be associated with more complete reporting for several checklist items

No systematic review has comprehensively reviewed evaluations of other reporting guidelines

\section{What this study adds}

Apart from CONSORT, 101 rigorously developed reporting guidelines exist for reporting health research, only nine of which could be evaluated regarding their journal endorsement status and with data from only a few evaluations

Few data are available to help editors regarding endorsement of specific reporting guidelines

Future evaluations of reporting guidelines based on journal endorsement status can help to supplement the evidence base

However, researchers should consider prospectively designed, controlled studies conducted in the context of the journal's editorial process to provide more robust evidence

15 Moher D, Hopewell S, Schulz KF, Montori V, Gotzsche PC, Devereaux PJ, et al. CONSORT 2010 explanation and elaboration: updated guidelines for reporting parallel group randomised trials. BMJ 2010;340:c869.

16 Turner L, Shamseer L, Altman DG, Weeks L, Peters J, Kober T, et al. Consolidated standards of reporting trials (CONSORT) and the completeness of reporting of randomised controlled trials (RCTs) published in medical journals. Cochrane Database Syst Rev 2012;11:MR000030.

17 Turner L, Shamseer L, Altman DG, Schulz KF, Moher D. Does use of the CONSORT Statement impact the completeness of reporting of randomised controlled trials published in medical journals? A Cochrane review. Syst Rev 2012;1:60

18 Shamseer L, Stevens A, Skidmore B, Turner LA, Altman DG, Hirst A, et al. Does journal endorsement of reporting guidelines influence the completeness of reporting of health research? A systematic review protocol. Syst Rev 2012;1:24.

19 Moher D, Liberati A, Tetzlaff J, Altman DG, Altman D, Antes G, et al. Preferred reporting items for systematic reviews and meta-analyses: the PRISMA statement. PLOS Med 2009;6:e1000097.

20 Review Manager [computer program]. Version 5.2. The Nordic Cochrane Centre, The Cochrane Collaboration, 2012. Available at http://tech.cochrane.org/revman.

21 Comprehensive Meta Analysis [computer program]. Version 2.2. BioStat, 2013.

22 Little J, Higgins JP, loannidis JP, Moher D, Gagnon F, von EE, et al. STrengthening the REporting of Genetic Association Studies (STREGA): an extension of the STROBE statement. PLoS Med 2009;6:e22.

23 Kilkenny C, Browne WJ, Cuthill IC, Emerson M, Altman DG. Improving bioscience research reporting: the arrive guidelines for reporting animal research. PloS Biol 2010;8:e1000412.

24 Hooijmans CR, Leenaars M, Ritskes-Hoitinga M. A gold standard publication checklist to improve the quality of animal studies, to fully integrate the three Rs, and to make systematic reviews more feasible. Altern Lab Anim 2010;38:167-82.

25 Stock-Schroer B, Albrecht H, Betti L, Endler PC, Linde K, Ludtke R, et al. Reporting experiments in homeopathic basic research (REHBaR)-a detailed guideline for authors. Homeopathy 2009;98:287-98

26 Kelly WN, Arellano FM, Barnes J, Bergman U, Edwards IR, Fernandez AM, et al. Guidelines for submitting adverse event reports for publication. Pharmacoepidemiol Drug Saf 2007;16:581-7.

27 Berger ML, Mamdani M, Atkins D, Johnson ML. Good research practices for comparative effectiveness research: defining, reporting and interpreting nonrandomized studies of treatment effects using secondary data sources: the ISPOR Good Research Practices for Retrospective Database Analysis Task Force Report—Part I. Value Health 2009;12:1044-52.

28 Bossuyt PM, Reitsma JB, Bruns DE, Gatsonis CA, Glasziou PP, Irwig LM, et al. Towards complete and accurate reporting of studies of diagnostic accuracy: the STARD initiative. Clin Chem 2003;49:1-6.

29 Bruns DE, Huth EJ, Magid E, Young DS. Toward a checklist for reporting of studies of diagnostic accuracy of medical tests. Clin Chem 2000;46:893-5.

30 Donahue SP, Arnold RW, Ruben JB. Preschool vision screening: what should we be detecting and how should we report it? Uniform guidelines for reporting results of preschool vision screening studies. J AAPOS 2003;7:314-6.

31 Gardner IA, Nielsen SS, Whittington RJ, Collins MT, Bakker D, Harris B, et al. Consensus-based reporting standards for diagnostic test accuracy studies for paratuberculosis in ruminants. Prev Vet Med 2011;101(1-2):18-34.

32 Drummond MF, Jefferson TO, for the BMJ Economic Evaluation Working Party. Guidelines for authors and peer reviewers of economic submissions to the BMJ. BMJ 1996;313:275-83.

33 Ramsey S, Willke R, Briggs A, Brown R, Buxton M, Chawla A, et al. Good research practices for cost-effectiveness analysis alongside clinical trials: the ISPOR RCT-CEA Task Force report. Value Health 2005;8:521-33.

34 Siegel JE, Weinstein MC, Russell LB, Gold MR. Recommendations for reporting cost-effectiveness analyses: Panel on Cost-Effectiveness in Health and Medicine. JAMA 1996;276:1339-41.

35 Davis JC, Robertson MC, Comans T, Scuffham PA. Guidelines for conducting and reporting economic evaluation of fall prevention strategies. Osteoporos Int 2011;22:2449-59.

36 Nicholson A, Berger K, Bohn R, Carcao M, Fischer K, Gringeri A, et al. Recommendations for reporting economic evaluations of haemophilia prophylaxis: a nominal groups consensus statement on behalf of the Economics Expert Working Group of the International Prophylaxis Study Group. Haemophilia 2008;14:127-32.

37 Talmon J, Ammenwerth E, Brender J, de Keizer N, Nykanen P, Rigby M. STARE-HI-Statement on reporting of evaluation studies in Health Informatics. Int J Med Inf 2009;78:1-9.

38 Robinson TN, Patrick K, Eng TR, Gustafson D. An evidence-based approach to interactive health communication: a challenge to medicine in the information age. JAMA 1998;280:1264-9

39 Brown P, Brunnhuber K, Chalkidou K, Chalmers I, Clarke M, Fenton M, et al. How to formulate research recommendations. BMJ 2006;333:804-6.
40 Rochon PA, Hoey J, Chan AW, Ferris LE, Lexchin J, Kalkar SR, et al. Financial Conflicts of Interest Checklist 2010 for clinical research studies. Open Med 2010;4:e69-91.

41 Research Information Network. Acknowledgement of funders in scholarly journal articles: guidance for UK research funders, authors and publishers. 2008. www.rin.ac.uk/system/ files/attachments/Acknowledgement-funders-guidance.pdf.

42 Graf C, Battisti WP, Bridges D, Bruce-Winkler V, Conaty JM, Ellison JM, et al. Good publication practice for communicating company sponsored medical research: the GPP2 guidelines. BMJ 2009;339:b4330.

43 Lindon JC, Nicholson JK, Holmes E, Keun HC, Craig A, Pearce JTM, et al. Summary recommendations for standardization and reporting of metabolic analyses. Nat Biotechnol 2005;23:833-8.

44 Sung L, Hayden J, Greenberg ML, Koren G, Feldman BM, Tomlinson GA. Seven items were identified for inclusion when reporting a Bayesian analysis of a clinical study. J Clin Epidemiol 2005:58:261-8.

45 Dean ME, Coulter MK, Fisher P, Jobst K, Walach H. Reporting data on homeopathic treatments (RedHot): a supplement to CONSORT. Homeopathy 2007;96:42-5.

46 Moore HM, Kelly AB, Jewell SD, McShane LM, Clark DP, Greenspan R, et al. Biospecimen reporting for improved study quality (BRISQ). Cancer Cytopathol 2011;119:92-101.

47 From the Immunocompromised Host Society. The design, analysis, and reporting of clinical trials on the empirical antibiotic management of the neutropenic patient: report of a consensus panel. J Infect Dis 1990;161:397-401.

48 Gnekow AK, for the SIOP Brain Tumor Subcommittee, International Society of Pediatric Oncology. Recommendations of the Brain Tumor Subcommittee for the reporting of trials. Med Pediatr Oncol 1995;24:104-8.

49 Lux AL, Osborne JP. A proposal for case definitions and outcome measures in studies of infantile spasms and West syndrome: consensus statement of the West Delphi group. Epilepsia 2004;45:1416-28.

50 Scher HI, Eisenberger M, D'Amico AV, Halabi S, Small EJ, Morris M, et al. Eligibility and outcomes reporting guidelines for clinical trials for patients in the state of a rising prostate-specific antigen: recommendations from the Prostate-Specific Antigen Working Group. J Clin Oncol 2004;22:537-56.

51 Helmhout PH, Staal JB, Maher CG, Petersen T, Rainville J, Shaw WS. Exercise therapy and low back pain: insights and proposals to improve the design, conduct, and reporting of clinical trials. Spine (Phila Pa 1976) 2008;33:1782-8.

52 Aletaha D, Landewe R, Karonitsch T, Bathon J, Boers M, Bombardier C, et al. Reporting disease activity in clinical trials of patients with rheumatoid arthritis: EULAR/ACR collaborative recommendations. Ann Rheum Dis 2008;67:1360-4.

53 Higashida RT, Furlan AJ, Roberts H, Tomsick T, Connors B, Barr J, et al. Trial design and reporting standards for intra-arterial cerebral thrombolysis for acute ischemic stroke. Stroke 2003;34:e109-37.

54 Diehm N, Baumgartner I, Jaff M, Do DD, Minar E, Schmidli J, et al. A call for uniform reporting standards in studies assessing endovascular treatment for chronic ischaemia of lower limb arteries. Eur Heart J 2007;28:798-805.

55 Nedeltchev K, Pattynama PM, Biaminoo G, Diehm N, Jaff MR, Hopkins LN, et al. Standardized definitions and clinical endpoints in carotid artery and supra-aortic trunk revascularization trials. Catheter Cardiovasc Interv 2010;76:333-44.

56 Rao SV, Eikelboom J, Steg PG, Lincoff AM, Weintraub WS, Bassand JP, et al. Standardized reporting of bleeding complications for clinical investigations in acute coronary syndromes: a proposal from the academic bleeding consensus (ABC) multidisciplinary working group. Am Heart J 2009;158:881-6.

57 Vitek JL, Lyons KE, Bakay R, Benabid AL, Deuschl G, Hallett M, et al. Standard guidelines for publication of deep brain stimulation studies in Parkinson's disease (Guide4DBS-PD). Mov Disord 2010;25:1530-7.

58 Orchard S, Salwinski L, Kerrien S, Montecchi-Palazzi L, Oesterheld M, Stumpflen V, et al. The minimum information required for reporting a molecular interaction experiment (MIMIx). Nat Biotechnol 2007;25:894-8.

59 Stephenson EL, Braude PR, Mason C. International community consensus standard for reporting derivation of human embryonic stem cell lines. Regen Med 2007;2:349-62.

60 Maxwell KL, Wildes D, Zarrine-Afsar A, De Los Rios MA, Brown AG, Friel CT, et al. Protein folding: defining a "standard" set of experimental conditions and a preliminary kinetic data set of two-state proteins. Protein Sci 2005;14:602-16.

61 Deutsch EW, Ball CA, Berman JJ, Bova GS, Brazma A, Bumgarner RE, et al. Minimum information specification for in situ hybridization and immunohistochemistry experiments (MISFISHIE). Nat Biotechnol 2008;26:305-12.

62 Harris RK, Becker ED, Cabral De Menezes SM, Granger P, Hoffman RE, Zilm KW. Further conventions for NMR shielding and chemical shifts IUPAC recommendations 2008. Solid State Nucl Magn Reson 2008;33(3):41-56.

63 Markley JL, Bax A, Arata Y, Hilbers CW, Kaptein R, Sykes BD, et al. Recommendations for the presentation of NMR structures of proteins and nucleic acids: IUPAC-IUBMB-IUPAB Inter-Union Task Group on the Standardization of Data Bases of Protein and Nucleic Acid Structures Determined by NMR Spectroscopy. J Biomol NMR 1998;12(1):1-23. 
64 Morton D, Kemp RK, Francke-Carroll S, Jensen K, McCartney J, Monticello TM, et al. Best practices for reporting pathology interpretations within GLP toxicology studies. Toxicol Pathol 2006;34:806-9.

65 Taylor CF, Paton NW, Lilley KS, Binz PA, Julian RK Jr, Jones AR, et al. The minimum information about a proteomics experiment (MIAPE). Nat Biotechnol 2007;25:887-93.

66 Taylor CF, Binz PA, Aebersold R, Affolter M, Barkovich R, Deutsch EW, et al. Guidelines for reporting the use of mass spectrometry in proteomics. Nat Biotechnol 2008:26:860-1.

67 Idris AH, Becker LB, Ornato JP, Hedges JR, Bircher NG, Chandra NC, et al. Utstein-style guidelines for uniform reporting of laboratory CPR research. Circulation 1996;94:2324-36.

68 Von Elm E, Altman DG, Egger M, Pocock SJ, Gotzsche PC, Vandenbroucke JP. The Strengthening the Reporting of Observational Studies in Epidemiology (STROBE) statement: guidelines for reporting observational studies. PLoS Med 2007;4:e296.

69 Tooth L, Ware R, Bain C, Purdie DM, Dobson A. Quality of reporting of observational longitudinal research. Am J Epidemiol 2005;161:280-8.

70 Gallo V, Egger M, McCormack V, Farmer PB, loannidis JPA, Kirsch-Volders M, et al. STrengthening the Reporting of OBservational studies in Epidemiology—Molecular Epidemiology (STROBE-ME): an extension of the STROBE statement. Eur $\mathrm{J}$ Clin Invest 2012;42:1-16.

71 McShane LM, Altman DG, Sauerbrei W, Taube SE, Gion M, Clark GM. REporting recommendations for tumour MARKer prognostic studies (REMARK). Eur J Cancer 2005:41:1690-6.

72 Dixon WG, Carmona L, Finckh A, Hetland ML, Kvien TK, Landewe R, et al. EULAR points to consider when establishing, analysing and reporting safety data of biologics registers in rheumatology. Ann Rheum Dis 2010;69:1596-602.

73 Wolfe F, Lassere M, Van Der Heijde D, Stucki G, Suarez-Almazor M, Pincus T, et al. Preliminary core set of domains and reporting requirements for longitudinal observational studies in rheumatology. J Rheumatol 1999;26:484-9.

74 Zakrzewska JM, Lopez BC. Quality of reporting in evaluations of surgical treatment of trigeminal neuralgia: recommendations for future reports. Neurosurgery 2003;53:110-20.

75 DeVivo MJ, Biering-Sorensen F, New P, Chen Y. Standardization of data analysis and reporting of results from the International Spinal Cord Injury Core Data Set. Spinal Cord 2011;49:596-9.

76 Des Jarlais DC, Lyles C, Crepaz N. Improving the reporting quality of nonrandomized evaluations of behavioral and public health interventions: the TREND Statement. Am J Public Health 2004;94:361-6.

77 Stone SP, Cooper BS, Kibbler CC, Cookson BD, Roberts JA, Medley GF, et al. The ORION statement: guidelines for transparent reporting of outbreak reports and intervention studies of nosocomial infection. Lancet Infect Dis 2007:7:282-8.

78 Strevel EL, Chau NG, Pond GR, Murgo AJ, Ivy PS, Siu LL. Improving the quality of abstract reporting for phase I cancer trials. Clin Cancer Res 2008;14:1782-7.

79 Przepiorka D, Weisdorf D, Martin P, Klingemann HG, Beatty P, Hows J, et al. 1994 Consensus Conference on Acute GVHD Grading. Bone Marrow Transplant 1995;15:825-8.

80 Cheson BD, Bennett JM, Kopecky KJ, Buchner T, Willman CL, Estey EH, et al. Revised recommendations of the International Working Group for Diagnosis, Standardization of Response Criteria, Treatment Outcomes, and Reporting Standards for Therapeutic Trials in Acute Myeloid Leukemia. J Clin Oncol 2003;21:4642-9.

81 Elliott R, Fischer CT, Rennie DL. Evolving guidelines for publication of qualitative research studies in psychology and related fields. Br J Clin Psychol 1999;38:215-29.

82 Smith L, Rosenzweig L, Schmidt M. Best practices in the reporting of participatory action research: embracing both the forest and the trees. Couns Psychol 2010:38:1115-38.

83 Davidoff F, Batalden P, Stevens D, Ogrinc G, Mooney S, Standards for QUality Improvement Reporting Excellence Development Group. Publication guidelines for quality improvement studies in health care: evolution of the SQUIRE project. $J$ Gen Intern Med 2008;23:2125-30

84 Asilomar Working Group on Recommendations for Reporting of Clinical Trials in the Biomedical Literature. Checklist of information for inclusion in reports of clinical trials. Ann Intern Med 1996:124:741-3.

85 Standards of Reporting Trials Group. A proposal for structured reporting of randomized controlled trials. JAMA 1994;272:1926-31.

86 Campbell MK, Elbourne DR, Altman DG, for the CONSORT Group. CONSORT statement: extension to cluster randomised trials. BMJ 2004;328:702-8.

87 Campbell MK, Grimshaw JM, Elbourne DR. Intracluster correlation coefficients in cluster randomized trials: empirical insights into how should they be reported. BMC Med Res Methodol 2004:4:9.

88 Piaggio G, Elbourne DR, Altman DG, Pocock SJ, Evans SJ, for the CONSORT Group. Reporting of noninferiority and equivalence randomized trials: an extension of the CONSORT statement [correction in: JAMA 2006;296:1842]. JAMA 2006;295:1152-60.

89 Hopewell S, Clarke M, Moher D, Wager E, Middleton P, Altman DG, et al. CONSORT for reporting randomised trials in journal and conference abstracts. Lancet 2008:371:281-3.

90 Krzyzanowska MK, Pintilie M, Brezden-Masley C, Dent R, Tannock IF. Quality of abstracts describing randomized trials in the proceedings of American Society of Clinical Oncology meetings: guidelines for improved reporting. J Clin Oncol 2004;22:1993-9.

91 loannidis JP, Evans SJ, Gotzsche PC, O'Neill RT, Altman DG, Schulz K, et al. Better reporting of harms in randomized trials: an extension of the CONSORT statement. Ann Intern Med 2004;141:781-8.

92 Boutron I, Moher D, Altman DG, Schulz KF, Ravaud P, for the CONSORT Group. Methods and processes of the CONSORT Group: example of an extension for trials assessing nonpharmacologic treatments. Ann Intern Med 2008;148:W60-6.

93 Gagnier JJ, Boon H, Rochon P, Moher D, Barnes J, Bombardier C, et al. Reporting randomized, controlled trials of herbal interventions: an elaborated CONSORT statement. Ann Intern Med 2006;144:364-7.

94 Wu T-X, Li Y-P, Bian Z-X, Li T-Q, Li J, Dagenais S, et al. Consolidated standards for reporting trials of traditional Chinese medicine (CONSORT for TCM) (for solicitation of comments). Chinese Journal of Evidence-Based Medicine 2007;7:625-30.

95 MacPherson H, White A, Cummings M, Jobst KA, Rose K, Niemtzow RC, et al. Standards for Reporting Interventions in Controlled Trials of Acupuncture: the STRICTA recommendations. J Altern Complement Med 2002;8:85-9.

96 MacPherson H, Altman DG, Hammerschlag R, Youping L, Taixiang W, White A, et al. Revised STandards for Reporting Interventions in Clinical Trials of Acupuncture (STRICTA): extending the CONSORT statement. PLOS Med 2010;7:e1000261

97 Special report: measuring and reporting pain outcomes in randomized controlled trials. Technol Eval Cent Assess Program Exec Summ 2006;21:1-2.

98 Zwarenstein M, Treweek S, Gagnier JJ, Altman DG, Tunis S, Haynes B, et al. Improving the reporting of pragmatic trials: an extension of the CONSORT statement. BMJ 2008;337:a2390.
99 Bousquet PJ, Brozek J, Bachert C, Bieber T, Bonini S, Burney P, et al. The CONSORT statement checklist in allergen-specific immunotherapy: a GA2LEN paper. Allergy 2009;64:1737-45.

100 O'Connor AM, Sargeant JM, Gardner IA, Dickson JS, Torrence ME, Consensus MP, et al. The REFLECT statement: methods and processes of creating reporting guidelines for randomized controlled trials for livestock and food safety by modifying the CONSORT statement. Zoonoses Public Health 2010;57):95-104.

101 Rundback JH, Sacks D, Kent KC, Cooper C, Jones D, Murphy T, et al, for the American Heart Association. Guidelines for the reporting of renal artery revascularization in clinical trials. Circulation 2002;106:1572-85.

102 Goldberg SN, Grassi CJ, Cardella JF, Charboneau JW, Dodd GD III, Dupuy DE, et al. Image-guided tumor ablation: standardization of terminology and reporting criteria. Radiology 2005;235:728-39

103 APA Publications and Communications Board Working Group on Journal Article Reporting Standards. Reporting standards for research in psychology: why do we need them? What might they be? Am Psychol 2008;63:839-51.

104 Howley L, Szauter K, Perkowski L, Clifton M, McNaughton N. Quality of standardised patient research reports in the medical education literature: review and recommendations. Med Educ 2008;42:350-8.

105 Moher D, Cook DJ, Eastwood S, Olkin I, Rennie D, Stroup DF. Improving the quality of reports of meta-analyses of randomised controlled trials: the QUOROM statement. Lancet 1999;354:1896-900

106 Stroup DF, Berlin JA, Morton SC, Olkin I, Williamson GD, Rennie D, et al, for the Meta-analysis Of Observational Studies in Epidemiology (MOOSE) group. Meta-analysis of observational studies in epidemiology: a proposal for reporting. JAMA 2000;283.2008-12.

107 Kottner J, Audige L, Brorson S, Donner A, Gajewski BJ, Hrobjartsson A, et al. Guidelines for Reporting Reliability and Agreement Studies (GRRAS) were proposed. J Clin Epidemiol 2011;64:96-106.

108 Castren M, Karlsten R, Lippert F, Christensen EF, Bovim E, Kvam AM, et al. Recommended guidelines for reporting on emergency medical dispatch when conducting research in emergency medicine: the Utstein style. Resuscitation 2008;79:193-7.

109 Janssens AC, Ioannidis JP, van Duijn CM, Little J, Khoury MJ, for the GRIPS Group. Strengthening the reporting of Genetic RIsk Prediction Studies: the GRIPS Statement. PLoS Med 2011;8:e1000420.

110 Little J, Bradley L, Bray MS, Clyne M, Dorman J, Ellsworth DL, et al. Reporting, appraising and integrating data on genotype prevalence and gene-disease associations. Am J Epidemiol 2002;156:300-10.

111 Ad Hoc Committee on Reporting Standards, Society for Vascular Surgery/North American Chapter, International Society for Cardiovascular Surgery. Suggested standards for reports dealing with lower extremity ischemia. J Vasc Surg 1986;4:80-94.

112 Hollander JE, Blomkalns AL, Brogan GX, Diercks DB, Field JM, Garvey JL, et al. Standardized reporting guidelines for studies evaluating risk stratification of emergency department patients with potential acute coronary syndromes. Ann Emerg Med 2004:44:589-98.

113 Horstkotte D, Lengyel M, Mistiaen WP, Piper C, Voller H. Recommendations for reporting morbid events after heart valve surgery. J Heart Valve Dis 2005;14(1):1-7.

114 Landis RC, Murkin JM, Stump DA, Baker RA, Arrowsmith JE, De Somer F, et al. Consensus statement: minimal criteria for reporting the systemic inflammatory response to cardiopulmonary bypass. Heart Surg Forum 2010;13:E116-23.

115 Cummins RO, Chamberlain DA, Abramson NS, Allen M, Baskett PJ, Becker L, et al. Recommended quidelines for uniform reporting of data from out-of-hospital cardiac arrest: the utstein style. A statement for health professionals from a task force of the American Heart Association, the European Resuscitation Council, and Heart and Stroke Foundation of Canada, and the Australian Resuscitation Council. Circulation 1991;84:960-75.

116 Cummins RO, Chamberlain D, Hazinski MF, Nadkarni V, Kloeck W, Kramer E, et al. Recommended guidlines for reviewing, reporting, and conducting research on in-hospital resuscitation: the in-hospital 'Utstein style'. Acad Emerg Med 1997;4:603-27.

117 Zaritsky A, Nadkarni V, Hazinski MF, Foltin G, Quan L, Wright J, et al. Recommended guidelines for uniform reporting of pediatric advanced life support: the pediatric utstein style. Ann Emerg Med 1995;26:487-503.

118 Langhelle A, Nolan J, Herlitz J, Castren M, Wenzel V, Soreide E, et al. Recommended guidelines for reviewing, reporting, and conducting research on post-resuscitation care: the Utstein style. Resuscitation 2005;66:271-83.

119 Mason EE, Amaral J, Cowan GS Jr, Deitel M, Gleysteen JJ, Oria HE. Standards for reporting results. Obes Surg 1994;4:56-65.

120 Standards Committee, American Society for Bariatric Surgery. Guidelines for reporting results in bariatric surgery. Obes Surg 1997;7:521-2.

121 Benchimol El, Manuel DG, To T, Griffiths AM, Rabeneck L, Guttmann A. Developmen and use of reporting guidelines for assessing the quality of validation studies of health administrative data. J Clin Epidemiol 2011;64:821-9.

122 Herman PM, Craig BM, Caspi O. Is complementary and alternative medicine (CAM) cost-effective? A systematic review. BMC Complement Altern Med 2005;5

123 Jefferson T, Smith R, Yee Y, Drummond M, Pratt M, Gale R. Evaluating the BMJ guidelines for economic submissions: prospective audit of economic submissions to BMJ and the Lancet. JAMA 1998:280:275-7.

124 Haidich AB, Birtsou C, Dardavessis T, Tirodimos I, Arvanitidou M. The quality of safety reporting in trials is still suboptimal: survey of major general medical journals. $J$ Clin Epidemiol 2011;64:124-35

125 Turner LA, Singh K, Garritty C, Tsertsvadze A, Manheimer E, Wieland LS, et al. An evaluation of the completeness of safety reporting in reports of complementary and alternative medicine trials. BMC Complement Altern Med 2011:11:67.

126 Lee PE, Fischer HD, Rochon PA, Gill SS, Herrmann N, Bell CM, et al. Published randomized controlled trials of drug therapy for dementia often lack complete data on harm. J Clin Epidemiol 2008;61:1152-60.

127 Ernst E, Hung SK, Clement Y. NCCAM-funded RCTs of herbal medicines: an independent, critical assessment. Perfusion 2011;24:89-102.

128 Hind D, Booth A. Do health technology assessments comply with QUOROM diagram guidance? An empirical study. BMC Med Res Methodol 2007;7:49.

129 Biondi-Zoccai GG, Lotrionte M, Abbate A, Testa L, Remigi E, Burzotta F, et al. Compliance with QUOROM and quality of reporting of overlapping meta-analyses on the role of acetylcysteine in the prevention of contrast associated nephropathy: case study. BM 2006;332:202-6.

130 Poolman RW, Abouali JA, Conter HJ, Bhandari M. Overlapping systematic reviews of anterior cruciate ligament reconstruction comparing hamstring autograft with bone-patellar tendon-bone autograft: why are they different? J Bone Joint Surg Am 2007;89:1542-52. 
131 Freeman K, Szczepura A, Osipenko L. Non-invasive fetal RHD genotyping tests: a systematic review of the quality of reporting of diagnostic accuracy in published studies. Eur J Obstet Gynecol Reprod Biol 2009;142:91-8.

132 Mahoney J, Ellison J. Assessing the quality of glucose monitor studies: a critical evaluation of published reports. Clin Chem 2007;53:1122-8.

133 Selman TJ, Morris RK, Zamora J, Khan KS. The quality of reporting of primary test accuracy studies in obstetrics and gynaecology: application of the STARD criteria. BMC Womens Health 2011:11:8.

134 Smidt N, Rutjes AW, van der Windt DA, Ostelo RW, Bossuyt PM, Reitsma JB, et al. The quality of diagnostic accuracy studies since the STARD statement: has it improved? Neurology 2006;67:792-7.

135 Coppus SF, van der Veen F, Bossuyt PM, Mol BW. Quality of reporting of test accuracy studies in reproductive medicine: impact of the Standards for Reporting of Diagnostic Accuracy (STARD) initiative. Fertil Steril 2006:86:1321-9.

136 Johnson ZK, Siddiqui MA, Azuara-Blanco A. The quality of reporting of diagnostic accuracy studies of optical coherence tomography in glaucoma. Ophthalmology 2007;114:1607-12.

137 Krzych LJ, Liszka L. No improvement in studies reporting the diagnostic accuracy of B-type natriuretic peptide. Med Sci Monit 2009;15:SR5-14.

138 Paranjothy B, Shunmugam M, Azuara-Blanco A. The quality of reporting of diagnostic accuracy studies in glaucoma using scanning laser polarimetry. J Glaucoma 2007;16:670-5.

139 Hammerschlag R, Milley R, Colbert A, Weih J, Yohalem-llsley B, Mist S, et al. Randomized controlled trials of acupuncture (1997-2007): an assessment of reporting quality with a CONSORT- and STRICTA-based instrument. Evid Based Complement Alternat Med 2011;2011:pii:183910.

140 Delaney M, Meyer E, Cserti-Gazdewich C, Haspel RL, Lin Y, Morris A, et al. A systematic assessment of the quality of reporting for platelet transfusion studies. Transfusion 2010;50:2135-44.

141 Peron J, Maillet D, Gan HK, Chen EX, You B. Adherence to CONSORT adverse event reporting guidelines in randomized clinical trials evaluating systemic cancer therapy: a systematic review. J Clin Oncol 2013;31:3957-63.

142 Cornelius VR, Sauzet O, Williams JE, Ayis S, Farquhar-Smith P, Ross JR, et al. Adverse event reporting in randomised controlled trials of neuropathic pain: considerations for future practice. Pain 2013:154:213-20.

143 Tunis AS, McInnes MD, Hanna R, Esmail K. Association of study quality with completeness of reporting: have completeness of reporting and quality of systematic reviews and meta-analyses in major radiology journals changed since publication of the PRISMA statement? Radiology 2013;269:413-26.

144 Fleming PS, Seehra J, Polychronopoulou A, Fedorowicz Z, Pandis N. A PRISMA assessment of the reporting quality of systematic reviews in orthodontics. Angle Orthod 2013;83:158-63.

145 Panic N, Leoncini E, de Belvis G, Ricciardi W, Boccia S. Evaluation of the endorsement of the preferred reporting items for systematic reviews and meta-analysis (PRISMA) statement on the quality of published systematic review and meta-analyses. Plos One 2013;8:e83138.

146 Ghimire S, Kyung E, Lee H, Kim E. Oncology trial abstracts showed suboptimal improvement in reporting: a comparative before-and-after evaluation using CONSORT for Abstract guidelines. J Clin Epidemiol 2014;67:658-66.

147 Parsons NR, Hiskens R, Price CL, Achten J, Costa ML. A systematic survey of the quality of research reporting in general orthopaedic journals. J Bone Joint Surg Br 2011;93:1154-9.
148 Faggion CM Jr, Tu YK, Giannakopoulos NN. Reporting adverse events in randomized controlled trials in periodontology: a systematic review. J Clin Periodontol 2013:40:889-95.

$149 \mathrm{Kim} \mathrm{KH}$, Kang JW, Lee MS, Lee JD. Assessment of the quality of reporting for treatment components in Cochrane reviews of acupuncture. BMJ Open 2014;4:e004136.

150 Bastuji-Garin S, Sbidian E, Gaudy-Marqueste C, Ferrat E, Roujeau JC, Richard MA, et al. Impact of STROBE statement publication on quality of observational study reporting: interrupted time series versus before-after analysis. Plos One 2013;8:e64733.

151 Hodkinson A, Kirkham JJ, Tudur-Smith C, Gamble C. Reporting of harms data in RCTs: a systematic review of empirical assessments against the CONSORT harms extension. BMJ Open 2013;3:e003436.

152 Altman DG. Endorsement of the CONSORT statement by high impact medical journals: survey of instructions for authors. BMJ 2005;330:1056-7.

153 Hopewell S, Altman DG, Moher D, Schulz KF. Endorsement of the CONSORT Statement by high impact factor medical journals: a survey of journal editors and journal 'Instructions to Authors'. Trials 2008;9:20.

154 Smidt N, Overbeke J, De VH, Bossuyt P. Endorsement of the STARD Statement by biomedical journals: survey of instructions for authors. Clin Chem 2007;53:1983-5.

155 Meerpohl JJ, Wolff RF, Niemeyer CM, Antes G, von Elm E. Editorial policies of pediatric journals: survey of instructions for authors. Arch Pediatr Adolesc Med 2010:164:268-72.

156 Hirst A, Altman DG. Are peer reviewers encouraged to use reporting guidelines? A survey of 116 health research journals. Plos One 2012;7:e35621.

157 Shamseer L, Theilman J, Turner L, Hopewell S, Altman DG, Schulz KF, et al. Update on the endorsement of CONSORT by high impact factor journals: a survey of journal editors and instructions to authors. Seventh International Congress on Peer Review and Biomedical Publication, Chicago, USA, September 8-10, 2013.

158 Cobo E, Cortes J, Ribera JM, Cardellach F, Selva-O'Callaghan A, Kostov B, et al. Effect of using reporting guidelines during peer review on quality of final manuscripts submitted to a biomedical journal: masked randomised trial. BMJ 2011;343:d6783.

159 Canadian Institutes of Health Research. About knowledge translation. 2014. www.cihrirsc.gc.ca/e/29418.html.

160 Improved Clinical Effectiveness through Behavioural Research Group (ICEBeRG). Designing theoretically-informed implementation interventions. Implement Sci 2006;1:4.

161 French SD, Green SE, O'Connor DA, McKenzie JE, Francis JJ, Michie S, et al. Developing theory-informed behaviour change interventions to implement evidence into practice: a systematic approach using the Theoretical Domains Framework. Implement Sci 2012;7:38.

162 Fleming PS, Seehra J, Polychronopoulou A, Fedorowicz Z, Pandis N. Cochrane and non-Cochrane systematic reviews in leading orthodontic journals: a quality paradigm? Eur J Orthod 2013;35:244-8.

Accepted: 27 May 2014

\section{Cite this as: BMJ 2014;348:g3804}

This is an Open Access article distributed in accordance with the Creative Commons Attribution Non Commercial (CC BY-NC 3.0) license, which permits others to distribute, remix, adapt, build upon this work non-commercially, and license their derivative works on different terms, provided the original work is properly cited and the use is non-commercial. See: http://creativecommons.org/licenses/by-nc/3.0/. 


\section{Tables}

Table 1/ Characteristics of included evaluations for BMJ economics, CONSORT extension for abstracts, CONSORT extension for harms, CONSORT extension for herbal interventions, and PRISMA reporting guidelines

\begin{tabular}{|c|c|c|c|c|c|}
\hline Author, year* & $\begin{array}{l}\text { Country of } \\
\text { corresponding } \\
\text { author }\end{array}$ & $\begin{array}{l}\text { Sources of funding; role of funder; authors' } \\
\text { source(s) of support }\end{array}$ & Content focus & $\begin{array}{l}\text { Specific medical or } \\
\text { scientific specialty } †\end{array}$ & $\begin{array}{l}\text { Extent of guideline } \\
\text { assessed } \neq\end{array}$ \\
\hline \multicolumn{6}{|c|}{ BMJ economics guideline, 1996} \\
\hline Herman, $2005^{122} \S$ & United States & $\begin{array}{l}\text { Government agency: grant from National } \\
\text { Center for Complementary and Alternative } \\
\text { Medicine; not reported; not reported (authors } \\
\text { declare no competing interests) }\end{array}$ & $\begin{array}{l}\text { Complementary } \\
\text { medicine }\end{array}$ & Unspecified & All items \\
\hline Jefferson, $1998^{123}$ & United Kingdom & Not reported; not reported; not reported & Unspecified & Unspecified & Subset of items $\uparrow$ \\
\hline \multicolumn{6}{|c|}{ CONSORT extension for abstracts, $2008^{\star \star}$} \\
\hline Ghimire, $2014^{146}$ & South Korea & $\begin{array}{l}\text { Not reported; not reported; not reported } \\
\text { (authors declare no competing interests) }\end{array}$ & Unspecified & Oncology & Subset of items $\mathbb{\|}$ \\
\hline \multicolumn{6}{|c|}{ CONSORT extension for harms, $2004^{\star \star}$} \\
\hline Haidich, $2011^{124} \S$ & Greece & Not reported; not reported; not reported & Drug therapies & $\begin{array}{l}\text { Several medical } \\
\text { specialtiest† }\end{array}$ & All items \\
\hline Turner, $2011^{125} \S$ & Canada & $\begin{array}{l}\text { Government agency: National Center for } \\
\text { Complementary and Alternative Medicine, } \\
\text { National Institutes of Health; not reported; } \\
\text { authors declare no competing interests }\end{array}$ & $\begin{array}{l}\text { Complementary } \\
\text { medicine }\end{array}$ & Unspecified & 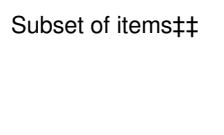 \\
\hline Peron, $2014^{141}$ & France & $\begin{array}{l}\text { Not reported; not reported; charitable } \\
\text { foundation: Nuovo-Soldati Foundation (authors } \\
\text { declare no competing interests) }\end{array}$ & Drugs therapies & Oncology & 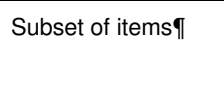 \\
\hline Cornelius, $2013^{142}$ & United Kingdom & $\begin{array}{l}\text { Government agency: National Institute for } \\
\text { Health Research Biomedical Research Centre } \\
\text { at Guy's and St Thomas' NHS Foundation } \\
\text { Trust and King's College London; not reported; } \\
\text { not reported (authors declare no competing } \\
\text { interests) }\end{array}$ & Drug therapies & Neurosciences & Subset of items \\
\hline Lee, $2008^{126}$ & Canada & $\begin{array}{l}\text { Government agency: Canadian Institutes of } \\
\text { Health Research Chronic Disease New } \\
\text { Emerging Team grant (joint sponsorship from } \\
\text { Canadian Diabetes Association, Kidney } \\
\text { Foundation of Canada, Heart and Stroke } \\
\text { Foundation of Canada, and two other Canadian } \\
\text { Institutes of Health Research Institutes); not } \\
\text { reported; not reported }\end{array}$ & Drug therapies & Clinical neurology & Subset of items \\
\hline \multicolumn{6}{|c|}{ CONSORT extension for herbal interventions, $\mathbf{2 0 0 6}^{\star \star}$} \\
\hline Ernst, $2011^{127}$ & United Kingdom & Not reported; not reported; not reported & $\begin{array}{l}\text { Complementary } \\
\text { medicine }\end{array}$ & $\begin{array}{l}\text { Medicine, general and } \\
\text { internal }\end{array}$ & Subset of items \\
\hline \multicolumn{6}{|l|}{ PRISMA, 2009} \\
\hline Tunis, $2013^{143} \S$ & Canada & $\begin{array}{l}\text { No funding; not applicable; not reported } \\
\text { (authors state no competing interests; authors } \\
\text { have declared financial activities not related to } \\
\text { article) }\end{array}$ & Unspecified & $\begin{array}{l}\text { Radiology, nuclear } \\
\text { medicine, and medical } \\
\text { imaging }\end{array}$ & All items \\
\hline Panic, $2013^{145} \S$ & Italy & $\begin{array}{l}\text { Not reported; funder had no role in work; } \\
\text { Academic: ERAWEB, Charitable: Fondazione } \\
\text { Veronesi (authors declare no competing } \\
\text { interests) }\end{array}$ & Unspecified & $\begin{array}{l}\text { Gastroenterology and } \\
\text { hepatology }\end{array}$ & All items \\
\hline Fleming, $2013^{144} \S$ & United Kingdom & Not reported; not reported; not reported. & Unspecified & $\begin{array}{l}\text { Dentistry, oral surgery, } \\
\text { and medicine }\end{array}$ & All items \\
\hline
\end{tabular}

*All included evaluations were published as full reports.

†2011 journal impact factor categories used for classification.

\#lf authors of evaluations deemed particular guidance item to be "not applicable" to literature they were assessing, those items were excluded from analysis; for evaluations with zero or one studies in one comparison arm, those evaluations were removed from synthesis because that one arm would determine direction of effect.

§lncluded in quantitative analysis.

IAs determined by authors of this review when comparing with published guidance. 
Table 1 (continued)

$\begin{array}{lllll} & \begin{array}{l}\text { Country of } \\ \text { corresponding }\end{array} & \begin{array}{l}\text { Sources of funding; role of funder; authors' } \\ \text { source(s) of support }\end{array} & \text { Specific medical or } & \text { Extent of guideline } \\ \text { Author, year* } & \text { author } & \text { Content focus } & \text { scientific specialty† }\end{array}$

**Official extension of CONSORT reporting guideline; "official" defined as at least one author from original CONSORT reporting guideline on authorship of extension. ††Cardiac and cardiovascular systems, hematology, immunology, infectious diseases, obstetrics and gynecology, oncology, psychiatry, respiratory system, and rheumatology.

¥¥Evaluation's authors indicated subset was assessed but authors of this review determined smaller subset was analyzed when comparing with published guidance. 


\begin{tabular}{|c|c|c|c|c|c|}
\hline Author, year* & $\begin{array}{l}\text { Country of } \\
\text { corresponding } \\
\text { author }\end{array}$ & $\begin{array}{l}\text { Sources of funding; role of funder; authors' } \\
\text { source(s) of support }\end{array}$ & Content focus & $\begin{array}{l}\text { Specific medical or } \\
\text { scientific specialty† }\end{array}$ & $\begin{array}{l}\text { Extent of guideline } \\
\text { assessed } \ddagger\end{array}$ \\
\hline \multicolumn{6}{|l|}{ QUOROM, 1999} \\
\hline Hind, $2007^{128} \S$ & United Kingdom & $\begin{array}{l}\text { Not reported; not reported; not reported (authors } \\
\text { declare they previously worked for UK NHS } \\
\text { Health Technology Assessment Programme } \\
\text { (source of included reports)) }\end{array}$ & $\begin{array}{l}\text { Therapeutic } \\
\text { interventions (generic) }\end{array}$ & Unspecified & Subset of items \\
\hline $\begin{array}{l}\text { Biondi-Zoccai, } \\
2006^{129}\end{array}$ & Italy & $\begin{array}{l}\text { No funding; not applicable; not reported (authors } \\
\text { declare no competing interests) }\end{array}$ & Drug therapies & Urology and nephrology & All items \\
\hline Poolman, $2007^{130}$ & Canada, Netherlands & $\begin{array}{l}\text { Not reported; not reported; academic: Canadian } \\
\text { Institutes of Health Research Canada Research } \\
\text { Chair; Industry: Merck Sharp and Dohme } \\
\text { Netherlands, Biomet Netherlands, Zimmer } \\
\text { Netherlands; other: Stichting Wetenschappelijk } \\
\text { Onderzoek Orthopaedische Chirurgie Fellowship, } \\
\text { Anna Fonds Foundation, Nederlandse Vereniging } \\
\text { voor Orthopedische Traumatologie Fellowship }\end{array}$ & Surgery & Orthopedics & All items \\
\hline \multicolumn{6}{|l|}{ STARD, 2003} \\
\hline Freeman, $2009^{131} \S$ & United Kingdom & $\begin{array}{l}\text { Government agency: European Commission } \\
\text { funds allocated to Safe Activities For Everyone } \\
\text { Network of Excellence under 6th Framework; not } \\
\text { reported; not reported }\end{array}$ & $\begin{array}{l}\text { Biochemical and } \\
\text { laboratory research } \\
\text { methods }\end{array}$ & $\begin{array}{l}\text { Obstetrics and } \\
\text { gynecology }\end{array}$ & All items \\
\hline Mahoney, $2007^{132} \S$ & United States & Industry: LifeScan Inc; not reported; study funder & $\begin{array}{l}\text { Diagnostic (glucose } \\
\text { monitoring) }\end{array}$ & $\begin{array}{l}\text { Endocrinology and } \\
\text { metabolism }\end{array}$ & All items \\
\hline Selman, $2011^{133} \S$ & United Kingdom & $\begin{array}{l}\text { Not reported; not reported; other: charitable } \\
\text { foundation (Wellbeing of Women) and Medical } \\
\text { Research Council/Royal College of Obstetricians } \\
\text { and Gynaecologists Clinical Research Training } \\
\text { Fellowship (authors declare no competing } \\
\text { interests) }\end{array}$ & Diagnostic studies & $\begin{array}{l}\text { Obstetrics and } \\
\text { gynecology }\end{array}$ & Subset of items \\
\hline Smidt, $2006^{134} \S$ & Netherlands & $\begin{array}{l}\text { Government agency: ZonMW; funder did not play } \\
\text { role in study or manuscript**; authors declare no } \\
\text { competing interests. }\end{array}$ & Diagnostic studies & $\begin{array}{l}\text { Medicine, general and } \\
\text { internal }\end{array}$ & Subset of items $\mathbb{I}$ \\
\hline Coppus, $2006^{135}$ & Netherlands & $\begin{array}{l}\text { Government agency: VIDI-program of ZonMW } \\
\text { and charitable foundation: Scientific foundation } \\
\text { of the Maxima Medical Center; } \\
\text { not reported; not reported }\end{array}$ & Diagnostic studies & Reproductive biology & Subset of items§ \\
\hline Johnson, $2007^{136}$ & United Kingdom & $\begin{array}{l}\text { Not reported; not reported; not reported (authors } \\
\text { declare no competing interests) }\end{array}$ & Diagnostic studies & Ophthalmology & Subset of items \\
\hline Krzych, $2009^{137}$ & Poland & Self financed; not applicable; not reported & Diagnostic studies & $\begin{array}{l}\text { Cardiac and } \\
\text { cardiovascular systems }\end{array}$ & Subset of items†† \\
\hline Paranjothy, $2007^{138}$ & United Kingdom & $\begin{array}{l}\text { No funding; not reported; authors state no } \\
\text { information to disclose }\end{array}$ & Diagnostic studies & Ophthalmology & All items \\
\hline \multicolumn{6}{|l|}{ STRICTA, 2002ł‡ } \\
\hline $\begin{array}{l}\text { Hammerschlag, } \\
2011^{139} \S\end{array}$ & United States & $\begin{array}{l}\text { Not reported; not reported; personnel support } \\
\text { from Oregon College of Oriental Medicine } \\
\text { research department and Helfgott Research } \\
\text { Institute of National College of Natural Medicine }\end{array}$ & $\begin{array}{l}\text { Complementary } \\
\text { Medicine }\end{array}$ & Unspecified & Subset of items \\
\hline \multicolumn{6}{|l|}{ STROBE, 2007} \\
\hline Parsons, $2011^{147} \S$ & United Kingdom & Not reported; not reported; not reported & Surgery & Orthopedics & All items \\
\hline Delaney, $2010^{140}$ & United States & $\begin{array}{l}\text { Industry: Biomedical Excellence for Safer } \\
\text { Transfusion collaborative (industry sponsored); } \\
\text { not reported; authors declare no competing } \\
\text { interests }\end{array}$ & Platelet transfusion & Hematology & Subset of items $\uparrow$ \\
\hline
\end{tabular}

*All included evaluations were published as full reports.

†2011 journal impact factor categories used for classification.

flf authors of evaluations deemed particular guidance item to be "not applicable" to literature they were assessing, those items were excluded from analysis; for evaluations with zero or one studies in one comparison arm, those evaluations were removed from synthesis because that one arm would determine direction of effect.

§lncluded in quantitative analysis. 
Table 2 (continued)

\begin{tabular}{|c|c|c|c|c|c|}
\hline Author, year* & $\begin{array}{l}\text { Country of } \\
\text { corresponding } \\
\text { author }\end{array}$ & $\begin{array}{l}\text { Sources of funding; role of funder; authors' } \\
\text { source(s) of support }\end{array}$ & Content focus & $\begin{array}{l}\text { Specific medical or } \\
\text { scientific specialty† }\end{array}$ & $\begin{array}{l}\text { Extent of guideline } \\
\text { assessed }\end{array}$ \\
\hline
\end{tabular}

IAs determined by authors of this review when comparing with published guidance.

${ }^{* *}$ Specifically, funding agency did not play role in design or conduct of study; collection, management, analysis, or interpretation of data; or preparation, review, or approval of manuscript.

††Authors of evaluations indicated subset was assessed, but authors of this review determined smaller subset was analyzed when comparing with published guidance.

$\ddagger \ddagger$ Unofficial extension of CONSORT reporting guideline. 


\begin{tabular}{|c|c|c|c|c|c|c|c|}
\hline Author, year & $\begin{array}{l}\text { Relevant studies } \\
\text { for assessment } \\
\text { (endorsing } v \\
\text { non-endorsing) }\end{array}$ & $\begin{array}{c}\text { Year of } \\
\text { publication of } \\
\text { assessed studies }\end{array}$ & $\begin{array}{l}\text { Journals that } \\
\text { published } \\
\text { assessed } \\
\text { studies }\end{array}$ & $\begin{array}{l}\text { Two or more } \\
\text { assessors for } \\
\text { completeness of } \\
\text { reporting }^{*}\end{array}$ & $\begin{array}{l}\text { No of items } \\
\text { assessed as } \\
\text { reported in } \\
\text { methods section* }\end{array}$ & $\begin{array}{l}\text { Comprehensive } \\
\text { search strategy* }\end{array}$ & $\begin{array}{c}\text { Balance of } \\
\text { studies per } \\
\text { journal in } \\
\text { comparison } \\
\text { groups }{ }^{\star} \dagger\end{array}$ \\
\hline \multicolumn{8}{|c|}{ BMJ economic guidelines, 1996} \\
\hline Herman, $2005^{122} \ddagger$ & $2 v 11$ & 2003-04 & $1 \vee 10$ & Unclear & High & Low & High \\
\hline Jefferson, $1998^{123}$ & $1 v 5$ & $1997-98 \S$ & $1 v 1$ & Unclear & Unclear & High & High \\
\hline \multicolumn{8}{|c|}{ CONSORT extension for abstracts, 2008} \\
\hline Ghimire, $2014^{146}$ & $74 \vee 234$ & $2010-12$ & $2 v 4$ & High & Unclear & Low & Low \\
\hline \multicolumn{8}{|c|}{ CONSORT extension for harms, 2004} \\
\hline Haidich, $2011^{124} \ddagger$ & $25 \vee 77$ & 2006 & $2 v 3$ & High & High & High & Low \\
\hline Turner, $2011^{125} \ddagger$ & $5 \vee 189$ & 2009 & $5 \vee 104$ & Low & High & Low & Low \\
\hline Peron, $2013^{141}$ & $43 v 282$ & 2007-11 & $2 v 8$ & Unclear & High & Low & Low \\
\hline Cornelius, $2013^{142}$ & $1 v 6$ & 2009 & $1 v 5$ & High & High & High & High \\
\hline Lee, $2008^{126}$ & $1 \vee 1$ & 2005 & $1 \mathrm{vs} 1$ & High & High & High & High \\
\hline \multicolumn{8}{|c|}{ CONSORT extension for herbal interventions, 2006} \\
\hline Ernst, $2011^{127}$ & $1 \vee 4$ & 2009 & $1 v 3$ & Unclear & High & Low & High \\
\hline \multicolumn{8}{|l|}{ PRISMA, 2009} \\
\hline Tunis, $2013^{143} \ddagger$ & $13 v 48$ & $2010-11$ & $1 v 8$ & High & High & Low & Low \\
\hline Panic, $2013^{145} \ddagger$ & $30 \vee 30$ & Jan-Oct 2012 & $6 v 10$ & High & High & Low & Unclear \\
\hline Fleming, $2013^{144} \ddagger$ & $20 v 2$ & $2009-11$ v 2010-11 & $2 v 1$ & High & High & Low & Low \\
\hline \multicolumn{8}{|l|}{ QUOROM, 1999} \\
\hline Biondi-Zoccai, $2006^{128}$ & $1 v 6$ & 2004 & $1 v 6$ & High & High & Low & High \\
\hline Poolman, $2007^{130}$ & $1 v 6$ & 2006 v 2005 & $1 v 5$ & High & Unclear & Low & High \\
\hline \multicolumn{8}{|l|}{ STARD, 2003} \\
\hline Freeman, $2009^{131} \mp$ & $3 v 9$ & 2004-05 & $2 v 7$ & Unclear & High & High & High \\
\hline Mahoney, $2007^{132} \ddagger$ & $6 v 20$ & $2003-05$ & $4 v 13$ & High & High & Low & High \\
\hline Selman, $2011^{133} \ddagger$ & $14 v 36$ & $2003-06$ & $6 v 22$ & High & Low & Low & Low \\
\hline Smidt, $2006^{134} \ddagger$ & $95 \vee 46$ & 2004 & $7 v 5$ & High & High & Low & Low \\
\hline Coppus, $2006^{135}$ & $8 v 19$ & 2004 & $1 v 1$ & Low & High & Unclear & High \\
\hline Johnson, $2007^{136}$ & $1 v 10$ & 2005 & $1 \vee 4$ & High & High & Low & High \\
\hline Krzych, $2009^{137}$ & $4 v 21$ & 2004-06 & $2 v 16$ & Unclear & High & Low & High \\
\hline Paranjothy, $2007^{138}$ & $1 v 8$ & 2005-06 & $1 v 4$ & High & High & Low & High \\
\hline \multicolumn{8}{|l|}{ STRICTA, 2002} \\
\hline $\begin{array}{l}\text { Hammerschlag, } \\
2011^{139} \ddagger\end{array}$ & $17 v 130$ & $2002-05$ & $3 v 64$ & Low & High & Low & Unclear \\
\hline \multicolumn{8}{|l|}{ STROBE, 2007} \\
\hline Parsons, $2011^{147} \ddagger$ & $9 v 38$ & 2008-10 & $2 v 6$ & Low & Unclear & Low & Low \\
\hline Delaney, $2010^{140}$ & $1 \vee 4$ & 2008 & $1 v 3$ & High & Unclear & Low & High \\
\hline
\end{tabular}

*High=high validity; low=low validity; unclear=unclear validity.

†Assessed once authors' data reorganized into comparison groups.

łIncluded in quantitative synthesis.

$\S$ Estimated based on information provided in article. 
Table 4 | Validity assessment for evaluations with studies enabling the after versus before journal comparison

\begin{tabular}{|c|c|c|c|c|c|c|c|c|}
\hline Author, year & $\begin{array}{l}\text { Relevant studies } \\
\text { for assessment } \\
\text { (after } v \text { before } \\
\text { endorsement) }\end{array}$ & $\begin{array}{l}\text { Year of publication } \\
\text { of assessed } \\
\text { studies }\end{array}$ & $\begin{array}{l}\text { Journals } \\
\text { that } \\
\text { published } \\
\text { assessed } \\
\text { studies }\end{array}$ & $\begin{array}{l}\text { Two or more } \\
\text { assessors for } \\
\text { completeness } \\
\text { of reporting* }\end{array}$ & $\begin{array}{l}\text { No of items } \\
\text { assessed as } \\
\text { reported in } \\
\text { methods } \\
\text { section* }\end{array}$ & $\begin{array}{l}\text { Comprehensive } \\
\text { search strategy* }\end{array}$ & $\begin{array}{l}\text { Balance of } \\
\text { studies per } \\
\text { journal in } \\
\text { comparison } \\
\text { groups* } \dagger\end{array}$ & $\begin{array}{l}\text { Sampling took } \\
\text { place in period } \\
\text { following } \\
\text { publication of } \\
\text { reporting } \\
\text { guideline }{ }^{*}+\end{array}$ \\
\hline \multicolumn{9}{|c|}{ BMJ economic guidelines, 1996} \\
\hline Jefferson, $1998^{123}$ & $1 v 8$ & $1997-98$ v 1994-95§ & 1 & Unclear & Unclear & High & High & Low \\
\hline \multicolumn{9}{|c|}{ CONSORT extension for abstracts, 2008} \\
\hline Ghimire, $2014^{146}$ & $74 \vee 16$ & $2010-12$ v 2005-07 & 2 & High & Unclear & Low & Low & Low \\
\hline \multicolumn{9}{|c|}{ CONSORT extension for harms, 2004} \\
\hline Lee, $2008^{126}$ & $1 v 2$ & 2005 v 1999-2000 & 1 & High & High & High & High & Low \\
\hline \multicolumn{9}{|l|}{ PRISMA, 2009} \\
\hline Panic, $2013^{145} \ddagger$ & $27 v 26$ & 2012 v 2008-11 & 6 & High & High & Low & Low & Unclear \\
\hline Fleming, $2013^{144} \ddagger$ & $14 v 12$ & $2009-11$ v 2006-09 & 1 & High & High & Low & High & Low \\
\hline \multicolumn{9}{|l|}{ QUOROM, 1999} \\
\hline Hind, $2007^{128} \ddagger$ & $13 \vee 15$ & 2005 v 2003 & 1 & Low & High & Low & High & High \\
\hline \multicolumn{9}{|l|}{ STARD, 2003} \\
\hline Smidt, $2006^{134} \ddagger$ & $95 \vee 78$ & 2004 v 2000 & 7 & High & High & Low & Unclear & Low \\
\hline Selman, $2011^{133}$ & $3 v 1$ & $2005-06$ v 2003 & 1 & High & Low & Low & Low & High \\
\hline \multicolumn{9}{|l|}{ STRICTA, 2002} \\
\hline $\begin{array}{l}\text { Hammerschlag, } \\
2011^{139} \ddagger\end{array}$ & $11 \vee 4$ & $\begin{array}{l}2003-05 v \\
1999-2001\end{array}$ & 2 & Low & High & Low & Unclear & Low \\
\hline \multicolumn{9}{|l|}{ STROBE, 2007} \\
\hline $\begin{array}{l}\text { Parsons, } \\
2011^{147} \ddagger\end{array}$ & $9 v 11$ & $2008-10$ v 2005-08 & 2 & Low & Unclear & Low & Low & Low \\
\hline
\end{tabular}

*High=high validity; low=low validity; unclear=unclear validity.

†Assessed once authors' data reorganized into comparison groups.

łIncluded in quantitative synthesis.

$\S$ Estimated based on information provided in article. 
Table 5| Journal endorsement information for evaluations assessing BMJ economics, CONSORT extension for abstracts, CONSORT extension for harms, CONSORT extension for herbal interventions, and PRISMA reporting guidelines

\begin{tabular}{|c|c|c|c|}
\hline Author, year & Endorsing journals that published assessed studies & Extent of endorsement & Date of endorsement provided \\
\hline \multicolumn{4}{|c|}{ BMJ economic guidelines, 1996} \\
\hline Herman, $2005^{122 *} \dagger$ & BMJ & Submit checklist & By journal, email \\
\hline Jefferson, $1998^{123}$ & BMJ & Submit checklist & By journal, email \\
\hline \multicolumn{4}{|c|}{ CONSORT extension for abstracts, 2008} \\
\hline Ghimire, 2014 146 & Lancet & Suggests use & By journal, email \\
\hline \multicolumn{4}{|c|}{ CONSORT extension for harms, 2004} \\
\hline \multirow[t]{2}{*}{ Haidich, $2011^{124 *} \dagger$} & Annals of Internal Medicine & Submit checklist & By journal, email \\
\hline & The Lancet & Submit checklist & By journal, email \\
\hline \multirow[t]{5}{*}{ Turner, $2011^{125 *} \dagger$} & The American Journal of Gastroenterology & Submit checklist & By journal, email \\
\hline & American Journal of Kidney Diseases & Suggests use & By journal, email \\
\hline & Applied Health Economics and Health Policy & Suggests use & By journal, email \\
\hline & JAMA & Submit checklist & Not provided \\
\hline & Phytomedicine & Suggests use & Not provided \\
\hline \multirow[t]{2}{*}{ Peron, $2014^{141} \dagger$} & Lancet & Submit checklist & By journal, email \\
\hline & Lancet Oncology & Submit checklist & By journal, email \\
\hline Cornelius, $2013^{142} \dagger$ & Lancet & Submit checklist & By journal, email \\
\hline Lee, $2008^{126}$ & BMJ & Submit checklist & By journal, email \\
\hline \multicolumn{4}{|c|}{ CONSORT extension for herbal interventions, 2006} \\
\hline Ernst, $2011^{127} \dagger$ & Annals of Internal Medicine & Suggests use & Not provided \\
\hline \multicolumn{4}{|l|}{ PRISMA, 2009} \\
\hline Tunis, $2013^{143 *} \dagger$ & Radiology & Suggests use & Unknown based on information given \\
\hline \multirow[t]{9}{*}{ Panic, 2013 $3^{145 *}$} & Alimentary Pharmacology and Therapeutics & \multirow{9}{*}{$\begin{array}{l}\text { Extent of endorsement at time of } \\
\text { - author's analysis unknown (all } \\
\text { - journals) }\end{array}$} & \multirow[t]{9}{*}{ Provided by author (all journals) } \\
\hline & American Journal of Gastroenterology & & \\
\hline & BMC Gastroenterology & & \\
\hline & Colorectal Disease & & \\
\hline & Diseases of the Colon and Rectum & & \\
\hline & Gut & & \\
\hline & Gut Pathogens & & \\
\hline & Hepatitis Monthly & & \\
\hline & HPB & & \\
\hline \multirow[t]{4}{*}{ Fleming, $2013^{144 \star}$} & $\begin{array}{l}\text { American Journal of Orthodontics and Dentofacial } \\
\text { Orthopedics }\end{array}$ & Submit checklist & By journal, email \\
\hline & Angle Orthodontist & Suggests use & Not provided \\
\hline & European Journal of Orthodontics & Submit checklist & By journal, email \\
\hline & Journal of Orthodontics & Suggests use & By journal, email \\
\hline
\end{tabular}

${ }^{*}$ Evaluations included in quantitative analysis.

†Endorsing versus non-endorsing journals comparison only. 


\begin{tabular}{|c|c|c|c|}
\hline Author, year & $\begin{array}{l}\text { Endorsing journals that published assessed } \\
\text { studies }\end{array}$ & Extent of endorsement & Date of endorsement provided \\
\hline \multicolumn{4}{|l|}{ QUOROM, 1999} \\
\hline Hind, $2007^{128 *} \dagger$ & UK NHS Health Technology Assessment Programme & Submit checklist & By evaluation \\
\hline Biondi-Zoccai, $2006^{129} \ddagger$ & Clinical Cardiology & Unknown based on information given & Unknown based on information given \\
\hline Poolman, $2007^{130} \neq$ & BMJ & Suggests use & Not provided \\
\hline \multicolumn{4}{|l|}{ STARD, 2003} \\
\hline \multirow[t]{2}{*}{ Freeman, $2009^{131 *} \ddagger$} & American Journal of Obstetrics and Gynecology & Submit checklist & Unknown based on information given \\
\hline & Molecular Diagnosis§ & Suggests use & Not provided \\
\hline \multirow[t]{4}{*}{ Mahoney, $2007^{132 *} \ddagger$} & $\begin{array}{l}\text { Archives of Disease in Childhood (including Fetal and } \\
\text { Neonatal Edition) }\end{array}$ & Suggests use & Unknown based on information given \\
\hline & Clinical Biochemistry & Suggests use & Not provided \\
\hline & Emergency Medicine Journal & Suggests use & Unknown based on information given \\
\hline & Journal of the Medical Association of Thailand & Suggests use & Not provided \\
\hline \multirow[t]{6}{*}{ Selman, $2011^{133 *}$} & American Journal of Obstetrics and Gynecology $\dagger$ & Submit checklist & Unknown based on information given \\
\hline & Cancert & Suggests use & Not provided \\
\hline & Clinical Radiology $\dagger$ & Suggests use & Not provided \\
\hline & Journal of the Medical Association of Thailand $\dagger$ & Suggests use & Not provided \\
\hline & Obstetrics and Gynecology & Suggests use & By journal, email \\
\hline & Radiology $\dagger$ & Suggests use & By journal website \\
\hline \multirow[t]{7}{*}{ Smidt, $2006^{134 *}$} & Annals of Internal Medicine & Suggests use & \multirow{7}{*}{$\begin{array}{l}\text { Journal website or by evaluation (all } \\
\text { journals) }\end{array}$} \\
\hline & BMJ & Suggests use & \\
\hline & Clinical Chemistry & Submit checklist & \\
\hline & JAMA & Suggests use & \\
\hline & The Lancet & Submit checklist & \\
\hline & Neurology & Submit checklist & \\
\hline & Radiology & Suggests use & \\
\hline Coppus, $2006^{135} \ddagger$ & Human Reproduction & Journal no longer endorses guideline & \\
\hline Johnson, $2007^{136} \ddagger$ & Ophthalmic and Physiologic Optics & Submit checklist & By journal, email \\
\hline \multirow[t]{2}{*}{ Krzych, $2009^{137} \ddagger$} & Clinical Chemistry** & Submit checklist & Reported in another evaluation \\
\hline & Heart & Suggests use & Not provided \\
\hline Paranjothy, $2007^{138} \neq$ & British Journal of Ophthalmology & Suggests use & Not provided \\
\hline \multicolumn{4}{|l|}{ STRICTA, 2002} \\
\hline \multirow[t]{3}{*}{ Hammerschlag, 2011 $1^{139 *}$} & Acupuncture in Medicine & Suggests use & By journal, email \\
\hline & Journal of Alternative and Complementary Medicine & Suggests use & By journal, email \\
\hline & Medical Acupuncture† & Suggests use & By journal, email \\
\hline \multicolumn{4}{|l|}{ STROBE, 2007} \\
\hline \multirow[t]{2}{*}{ Parsons, $2011^{147 \star}$} & Clinical Orthopaedics and Related Research & Suggests use & By journal, email \\
\hline & The Journal of Bone and Joint Surgery (American) & Suggests use & By journal, email \\
\hline Delaney, $2010^{140} \ddagger$ & Annals of Surgery & Suggests use & Not provided \\
\hline
\end{tabular}

${ }^{*}$ Evaluations included in quantitative analysis.

†After versus before journal endorsement comparison only.

‡Endorsing versus non-endorsing journals comparison only.

$\S$ Now published as Molecular Diagnosis and Therapy.

IIn quantitative analysis for endorsing versus non-endorsing journals only.

**Reported in another included evaluation. 
Table $7 \mid$ Analysis by mean summed score of items for reporting guideline checklists, endorsing versus non-endorsing journals ${ }^{\star}$

\begin{tabular}{|c|c|c|c|}
\hline Reporting guideline† & No of evaluations $¥$ & No of studies (total) & Effect estimate $(99 \% \mathrm{Cl})$ \\
\hline CONSORT extension for harms, 2004 & $1 \S$ & $25 \vee 77(102)$ & Mean difference 0.04 (-1.50 to 1.58$)$ \\
\hline PRISMA, 2009 & $3 \rrbracket$ & $63 v 80(143)$ & Standardized mean difference 0.53 (0.02 to 1.03 ) \\
\hline STARD, 2003 & $3^{* *}$ & $23 v 65(88)$ & Standardized mean difference 0.52 ( -0.11 to 1.16$)$ \\
\hline STRICTA, 2002 & $1 \dagger \dagger$ & $17 \vee 130(147)$ & Mean difference $1.42(-0.04$ to 2.88$)$ \\
\hline STROBE, 2007 & $1 \S$ & $9 \vee 38(47)$ & Mean difference 1.55 (-3.19 to 6.29$)$ \\
\hline
\end{tabular}

*Individual forest plots depicting these summary data are shown in appendix 7.

TQUOROM (two evaluations) was not estimable because of one study in one comparison arm per assessed evaluation.

$\ddagger$ Only evaluations that calculated summed score for report were included.

§All checklist items summed.

ISubset of items was summed for one evaluation.

** Subset of items was summed for two of three evaluations.

††Subset of items was summed. 
Table 8| Analysis by mean summed score for reporting guideline checklists, after versus before journal endorsement* Reporting guideline No of evaluationst No of studies (total) Effect estimate $(99 \% \mathrm{Cl})$

\begin{tabular}{llcc} 
PRISMA, 2009 & $2 \ddagger$ & $41 v 38(79)$ & Standardized mean difference $0.49(-0.10$ to 1.08$)$ \\
\hline STRICTA, 2002 & $1 \S$ & $11 v 4(15)$ & Mean difference $1.82(-2.49$ to 6.13$)$ \\
\hline STROBE, 2007 & $1 \ddagger$ & $9 v 11(20)$ & Mean difference $1.16(-3.97$ to 6.29$)$ \\
\hline
\end{tabular}

*Individual forest plots depicting these summary data are shown in appendix 7.

†Only evaluations that calculated summed score for report were included.

$\ddagger$ All checklist items were summed.

$\S$ Subset of items was summed. 
Table 9| Assessment of methodological quality within evaluations

\begin{tabular}{|c|c|}
\hline Author, year & Methodological quality assessment \\
\hline \multicolumn{2}{|c|}{ BMJ economic guidelines, 1996} \\
\hline Herman, $2005^{122}$ & $\begin{array}{l}\text { Evaluated economic evaluations on four criteria: randomization; prospective economic data collection; comparison group was usual } \\
\text { care; and study was not blinded or mandatory regarding participation. Both studies in endorsing arm met all four criteria compared } \\
\text { with } 5 / 11 \text { studies in non-endorsing arm }\end{array}$ \\
\hline \multicolumn{2}{|c|}{ CONSORT extension for herbal interventions, 2006} \\
\hline Ernst, $2011^{127}$ & $\begin{array}{l}\text { Assessed studies by using Cochrane risk of bias tool. Only study from endorsing journal was assessed as at moderate risk of bias. } \\
\text { Studies from non-endorsing journals were assessed at high }(n=2) \text { or moderate }(n=2) \text { risk of bias }\end{array}$ \\
\hline \multicolumn{2}{|l|}{ PRISMA, 2009} \\
\hline Tunis, $2013^{143}$ & $\begin{array}{l}\text { Assessed reviews by using AMSTAR. Using data provided by author, studies }(n=13) \text { from only endorsing journal scored mean of } 9.2 \\
\text { of } 11 \text { points, and studies }(n=48) \text { from non-endorsing journals scored } 7.6 \text { of } 11 \text { points }\end{array}$ \\
\hline Panic, $2013^{145}$ & $\begin{array}{l}\text { Assessed reviews by using AMSTAR. Data by item are not presented. Endorsing versus non-endorsing journals: using data provided } \\
\text { by author, mean summed score from studies }(n=30) \text { from endorsing journals was } 7.2 \text { (range } 2 \text { to } 9 \text { ), and those }(n=30) \text { from non-endorsing } \\
\text { journals scored } 6.4 \text { (range 1-9). After versus before journal endorsement: using data provided by author, mean summed score was } \\
7.3 \text { (range } 3-9, n=27 \text { articles) after journal endorsement and } 6.0 \text { (range } 0-9, n=26 \text { articles) before endorsement }\end{array}$ \\
\hline Fleming, $2013^{144}$ & Authors assessed reviews by using AMSTAR tool but analyzed across all included studies ${ }^{162}$ \\
\hline \multicolumn{2}{|l|}{ QUOROM, 1999} \\
\hline Biondi-Zoccai, $2006^{129}$ & $\begin{array}{l}\text { Assessed studies by using the Oxman and Guyatt index (range of } 1 \text { (minimal flaws) to } 7 \text { (extensive flaws)). Only study from endorsing } \\
\text { journal scored } 2 \text { on index; studies }(n=6) \text { from non-endorsing journals scored range of } 1-6 \text { points }\end{array}$ \\
\hline Poolman, $2007^{130}$ & $\begin{array}{l}\text { Used the Oxman and Guyatt index (maximum score } 7 \text { points). Only study from endorsing journal scored } 7 \text { points. Studies from } \\
\text { non-endorsing journals }(n=6) \text { scored range of } 1-6 \text { points; four studies scoring } 1 \text { or } 2 \text { points are considered to have "major flaws" } \\
\text { according to index }\end{array}$ \\
\hline \multicolumn{2}{|l|}{ STARD, 2003} \\
\hline Freeman, $2009^{131}$ & $\begin{array}{l}\text { Assessed eight aspects that authors state address internal and external validity of included studies: selective participant sampling; } \\
\text { lack of reporting ethnicity and/or sensitization status of participants; lack of reporting number of replicates, if done, that were used for } \\
\text { overall study outcome; lack of reporting failure rate; lack of including reported failure rate in analysis; difference in reported and adjusted } \\
\text { accuracy; lack of controlling for presence of fetal DNA; and lack of known genotypes in study as control. Raw data provided in tabular } \\
\text { form without summary in text. Studies }(n=3) \text { from endorsing journals ranged from } 2 \text { to } 4 \text { of } 8 \text { flaws. Studies }(n=8) \text { from non-endorsing } \\
\text { journals ranged from } 2 \text { to } 6 \text { flaws, and information from one study was not interpretable }\end{array}$ \\
\hline Krzych, $2009^{137}$ & Authors assessed studies by using QUADAS tool but analyzed across all included studies \\
\hline
\end{tabular}




\section{Figures}

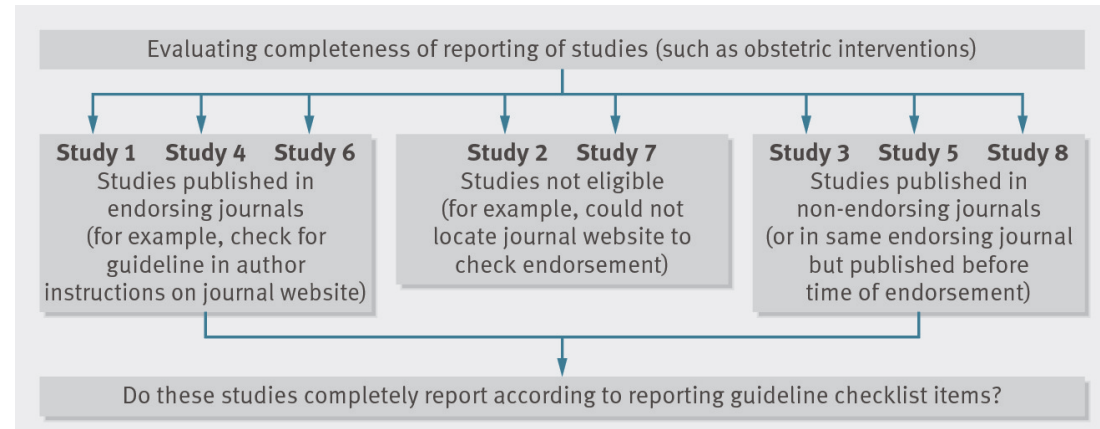

Fig 1 Schematic depicting relation among evaluation of reporting guideline, studies contained within it, and determination of comparison groups according to journal endorsement status

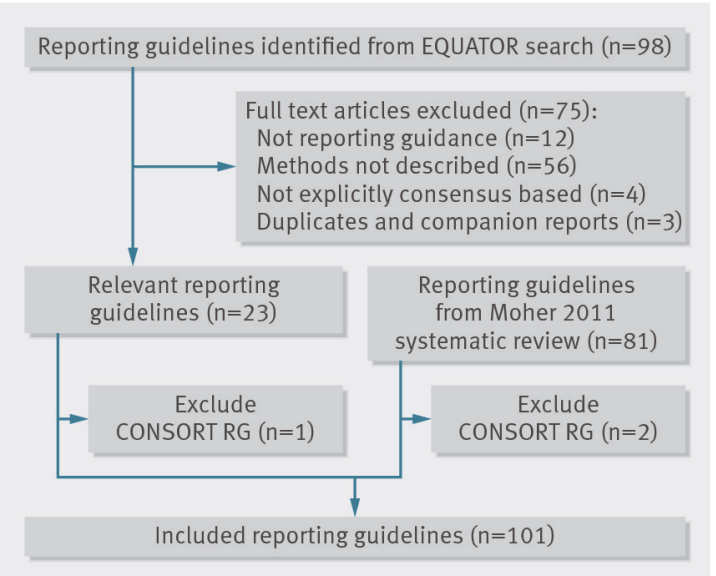

Fig 2 PRISMA flow diagram for selecting reporting guidelines for health research. RG=reporting guideline 


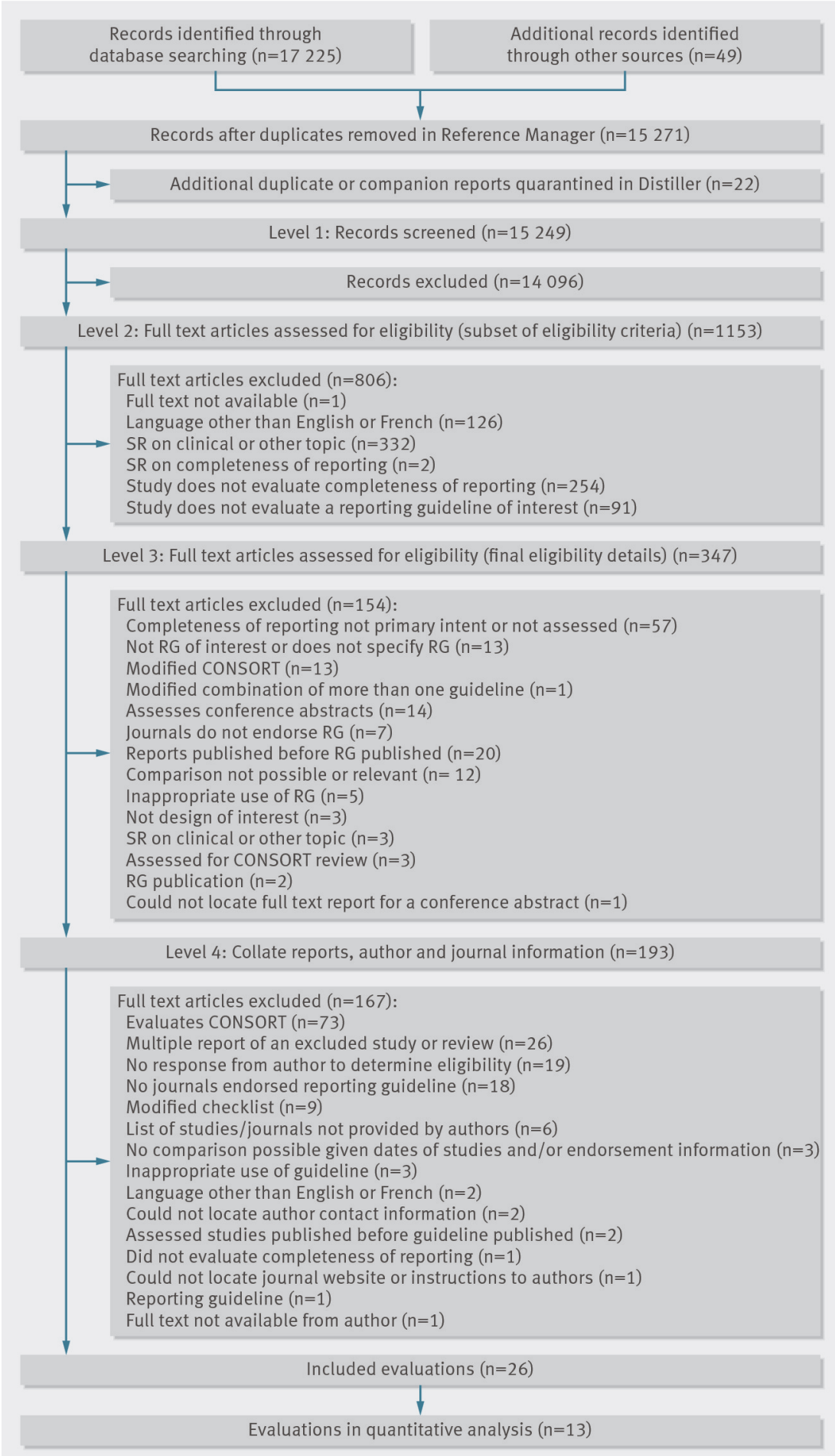

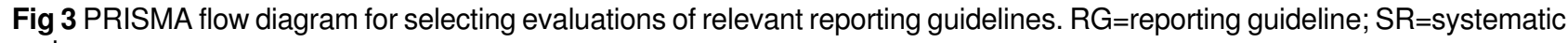
review 
BMJ Economics checklist items

Economic importance of question Clearly describe comparisons Form of economic evaluation Justify choice of economic evaluation Source(s) of effectiveness estimates Design and results of effectiveness study (single study) Primary economic evaluation outcome measure(s) Subjects from whom valuations obtained Quantities of resources separate from unit costs Methods for estimating quantities and unit costs Currency of price adjustments for inflation or currency conversion Time horizon of costs and benefits Statistical tests and $\mathrm{Cls}$ for stochastic data Compare relevant alternatives Incremental analysis

Major outcomes in aggregated and dissaggregated forms

Conclusions follow from data

Conclusions with appropriate caveats Answer to study question

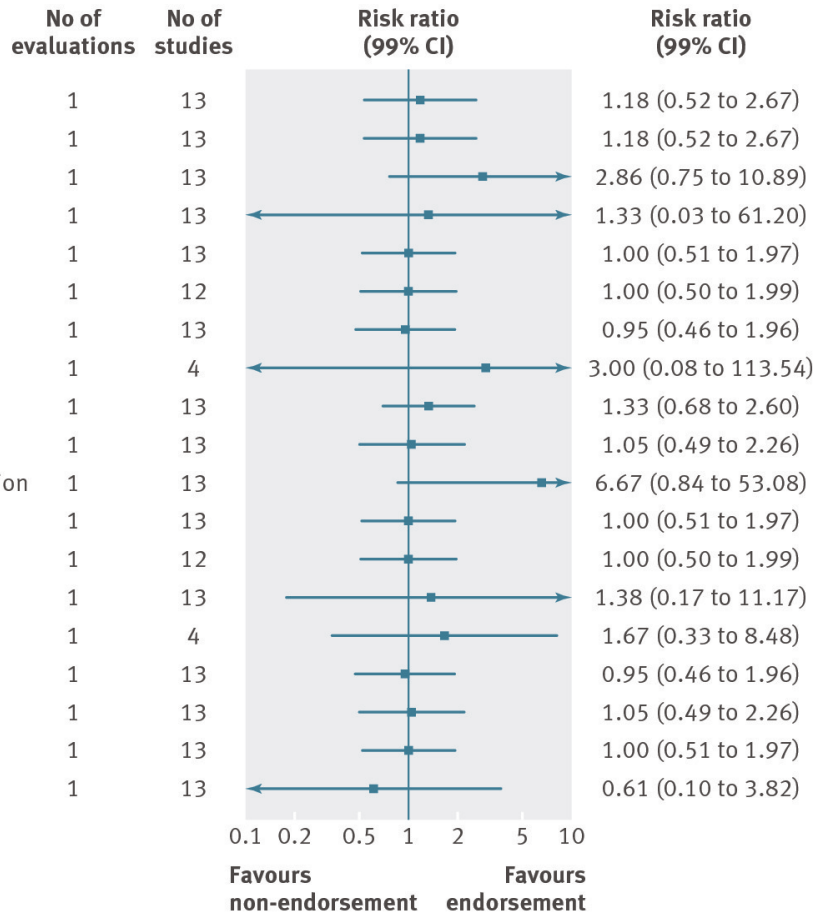

Fig 4 Completeness of reporting summary plot for BMJ economics checklist, endorsing versus non-endorsing journals. Summary plots in this and other related figures were generated in Comprehensive Meta-analysis. In brief, summary effect estimates for each checklist are shown, and those estimates were previously calculated in Review Manager. For example, checklist item "economic importance of question" was assessed in only one evaluation, which had 13 studies (2 studies from endorsing journal and 11 studies from non-endorsing journals; appendix 7) that provided information on whether study had reported on that checklist item. Appendix 7 shows analyses for each checklist item conducted in Review Manager

\begin{tabular}{cc}
$\begin{array}{c}\text { No of } \\
\text { evaluations }\end{array}$ & $\begin{array}{c}\text { No of } \\
\text { studies }\end{array}$ \\
\hline 1 & 102 \\
1 & 102 \\
2 & 296 \\
2 & 296 \\
2 & 296 \\
2 & 296 \\
2 & 296 \\
1 & 102 \\
1 & 102 \\
1 & 102
\end{tabular}

Title or abstract

Introduction

Outcomes - list adverse events and definitions

Outcomes - how information collected

Statistical methods - plans for presenting or analyzing harms

Participant flow

Numbers analyzed

Absolute risk for each adverse event and appropriate metrics

Subgroup and exploratory analyses

Discussion

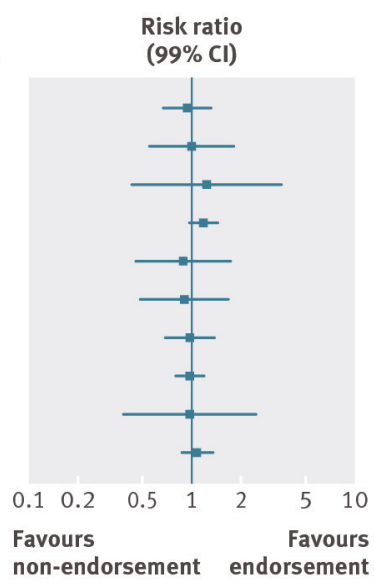

Risk ratio

$(99 \% \mathrm{Cl})$

0.94 (0.66 to 1.34$)$

1.00 (0.54 to 1.85$)$

1.24 (0.42 to 3.64$)$

1.18 (0.95 to 1.46$)$

0.89 (0.45 to 1.78$)$

$0.90(0.47$ to 1.72$)$

0.98 (0.68 to 1.41$)$

0.98 (0.79 to 1.22$)$

0.98 (0.38 to 2.53$)$

1.08 (0.85 to 1.37$)$

$\begin{array}{rr}\text { Favours } & \text { Favours } \\ \text { non-endorsement endorsement }\end{array}$

Fig 5 Completeness of reporting summary plot for CONSORT extension for harms checklist, endorsing versus non-endorsing journals 


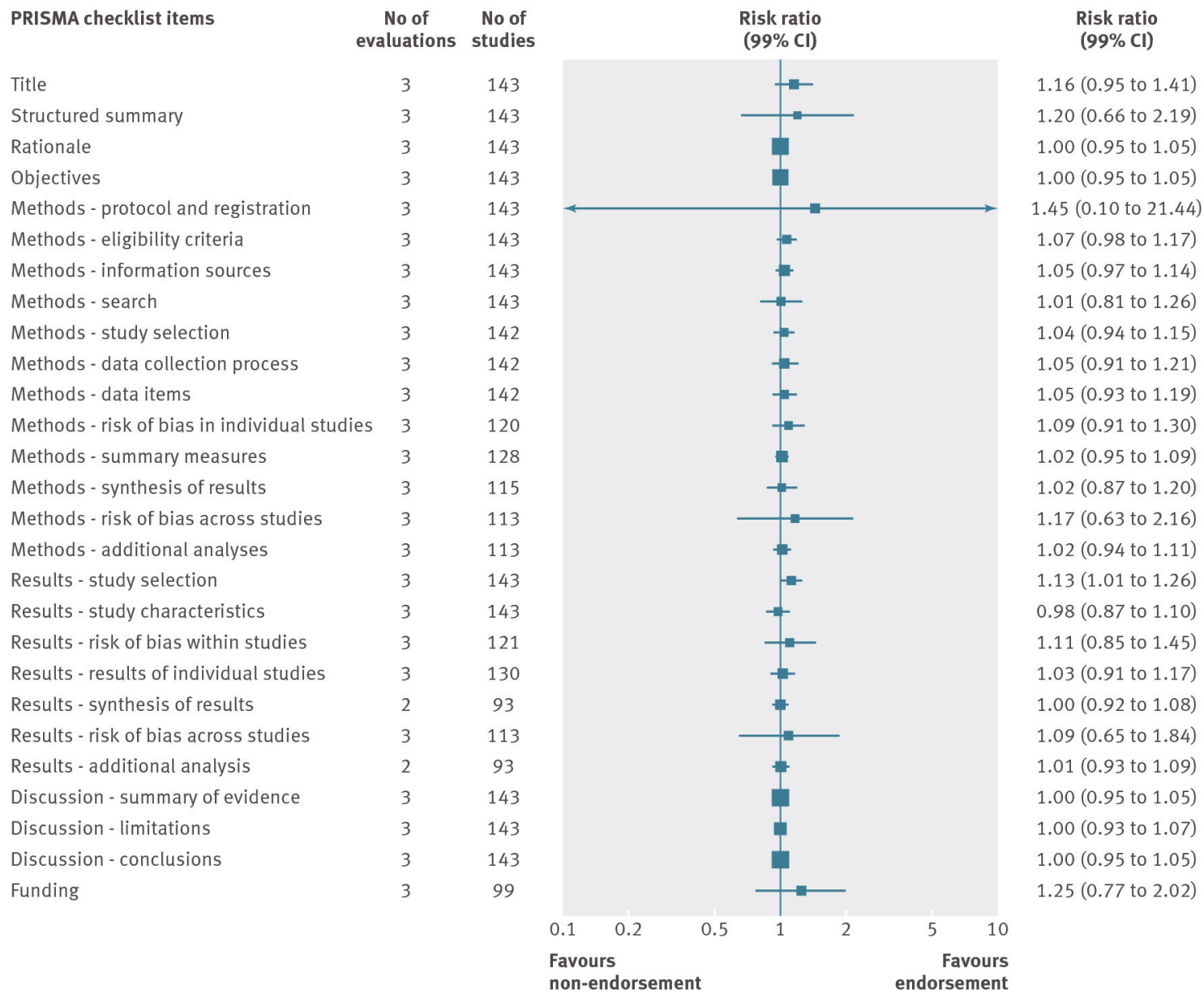

Fig 6 Completeness of reporting summary plot for PRISMA checklist, endorsing versus non-endorsing journals. Although all evaluations assessed all items, one evaluation was excluded from analysis of two checklist items because of zero or one studies for analysis 
STARD checklist items

Title, abstract, keywords

Introduction

Participants - study population

Participants - recruitment

Participants - sampling

Participants - data collection

Test methods - reference standard

Test methods - technical specifications

Test methods - persons reading test and reference

Test methods - readers blinded to other result?

Statistical methods - measures and uncertainty

Statistical methods - test reproducibility

Results - recruitment

Results - participant characteristics

Results - participant flow

Results - time interval from test to reference

Results - disease severity

Results - cross-tabulation of test by reference results

Results - any adverse events

Results - diagnostic accuracy estimates and uncertainty

Results - how indeterminate results, missing data, outliers handled

Results - variability between subgroups

Results - test reproducibility

Discussion

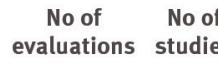

s

Risk ratio

$(99 \% \mathrm{Cl})$

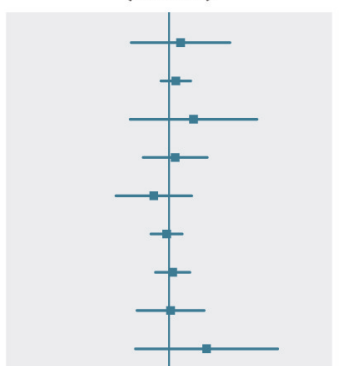

$(99 \% \mathrm{Cl})$

$1.13(0.55$ to 2.33$)$

$1.06(0.84$ to 1.33$)$

$1.36(0.55$ to 3.38$)$

1.06 (0.67 to 1.68$)$

0.78 (0.45 to 1.36$)$

$0.94(0.74$ to 1.19$)$

$1.02(0.79$ to 1.32$)$

$1.00(0.61$ to 1.64$)$

$1.67(0.60$ to 4.64$)$

0.83 (0.02 to 38.04)

2.42 (1.05 to 5.59 )

$0.56(0.12$ to 2.63$)$

0.81 (0.51 to 1.29$)$

1.73 (1.13 to 2.64$)$

1.33 (0.86 to 2.05$)$

$0.64(0.26$ to 1.57$)$

$0.73(0.08$ to 6.66$)$

1.26 (0.71 to 2.22$)$

$1.42(0.34$ to 5.98$)$

$1.85(0.72$ to 4.76$)$

1.41 (0.82 to 2.42$)$

$1.26(0.75$ to 2.11$)$

0.56 (0.12 to 2.63)

$1.00(0.89$ to 1.13$)$

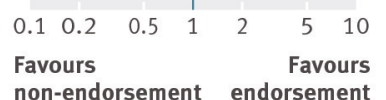

Fig 7 Completeness of reporting summary plot for STARD checklist, endorsing versus non-endorsing journals. Effect estimate for checklist item "Test methods: definition of cut-offs of index test and reference standard" was not estimable during quantitative analysis because of zero events in each arm (one evaluation in analysis)

STRICTA checklist items

Style of acupuncture

Rationale for treatment

Sources to justify rationale

Points used (uni/bilateral)

Numbers of needles inserted

Depths of insertion

Responses elicited

Needle stimulation

Needle retention time

Needle type

Number of treatment sessions

Frequency of treatment

Other interventions

Duration of relevant training

Length of clinical experience

Expertise in specific condition

Explanations given regarding treatment and control interventions

Sources that justify choice of control

No
evalua
1
1
1
1
1
1
1
1
1
1
1
1
1
1
1
1
1
1
1

\section{No of}

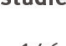

146

147

147

146

146

145

143

146

147

147

147

120

29

147

147

146

147

145
Risk ratio

$(99 \% \mathrm{Cl})$

$0.70(0.35$ to 1.39$)$

$1.04(0.72$ to 1.51$)$

1.41 (1.00 to 1.99 )

0.98 (0.72 to 1.34$)$

1.05 (0.72 to 1.53$)$

1.17 (0.62 to 2.21$)$

1.15 (0.72 to 1.84$)$

1.60 (1.25 to 2.04$)$

1.11 (0.86 to 1.44$)$

1.48 (0.93 to 2.36 )

$1.04(0.92$ to 1.17$)$

$1.06(0.86$ to 1.31$)$

0.87 (0.29 to 2.59$)$

1.39 (0.67 to 2.89$)$

$1.70(0.65$ to 4.43$)$

$1.52(0.34$ to 6.76$)$

1.13 (0.34 to 3.78$)$

1.11 (0.59 to 2.09$)$

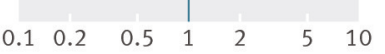

Favours Favours

non-endorsement endorsement

Fig 8 Completeness of reporting summary plot for STRICTA checklist, endorsing versus non-endorsing journals 
STROBE checklist items

Title or abstract

Abstract

Introduction - background and rationale Introduction - objectives

Methods - study design

Methods - setting, location, dates

Methods - participant eligibility

Methods - participant matching

Methods - outcome, exposure, other variables

Methods - data sources and measurement

Methods - addressing sources of bias

Methods - study size

Methods - handling of quantitative variables

Methods - statistical methods

Methods - subgroups and interactions

Methods - loss to follow-up, matching, sampling

Methods - sensitivity analyses

Results - participant flow

Results - reasons for nonparticipation

Results - flow diagram

Results - participant characteristics

Results - missing data

Results - follow-up time (cohort studies)

Results - outcome data

Results - estimates and precision

Results - boundaries for continuous variable categories 1

Results - translating relative into absolute risks

Results - other analyses

Discussion - key results

Discussion - limitations

Discussion - interpretation

Discussion - generalizability

Other - funding

$\begin{array}{cc}\text { No of } & \text { No of } \\ \text { evaluations } & \text { studies }\end{array}$

Risk ratio
$(99 \% \mathrm{Cl})$

47

47

47

47

47

47

47

24

47

47

47

47

47

47

47

42

47

47

47

47

47

47

10

47

47

44

35

46

47

47

47

47

47
Risk ratio

(99\% Cl)

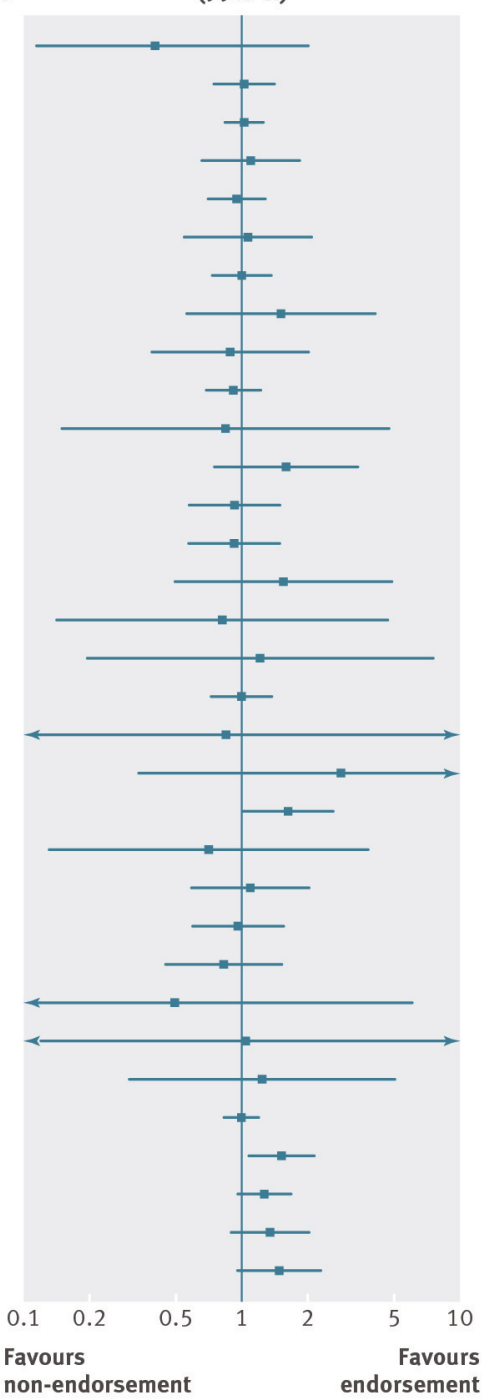

0.40 (0.08 to 2.09)

1.02 (0.73 to 1.43 )

1.02 (0.82 to 1.26$)$

1.09 (0.64 to 1.86$)$

0.94 (0.68 to 1.29)

1.06 (0.53 to 2.11)

0.99 (0.71 to 1.39$)$

1.50 (0.55 to 4.10$)$

0.88 (0.38 to 2.03 )

0.91 (0.67 to 1.24)

0.84 (0.15 to 4.87 )

1.58 (0.73 to 3.43 )

0.92 (0.56 to 1.51)

0.92 (0.56 to 1.51)

1.54 (0.48 to 4.93)

0.81 (0.14 to 4.76)

1.21 (0.19 to 7.53$)$

0.99 (0.71 to 1.39$)$

2.81 ( 0.33 to 24.14$)$

1.61 (0.99 to 2.61)

0.70 (0.13 to 3.93)

1.08 (0.56 to 2.08)

0.95 (0.58 to 1.56 )

0.82 (0.43 to 1.56 )

0.49 (0.04 to 6.27)

1.23 (0.30 to 5.02 )

0.99 (0.81 to 1.21)

1.51 (1.05 to 2.18 )

1.26 (0.93 to 1.70$)$

1.35 (0.88 to 2.07)

1.47 (0.93 to 2.32)

non-endorsement

endorsement

0.84 (0.06 to 12.01 )

1.04 (0.02 to 61.88$)$

Fig 9 Completeness of reporting summary plot for STROBE checklist, endorsing versus non-endorsing journals. Effect estimate for checklist item "Methods: missing data" was not estimable during quantitative analysis because of zero events in each arm 


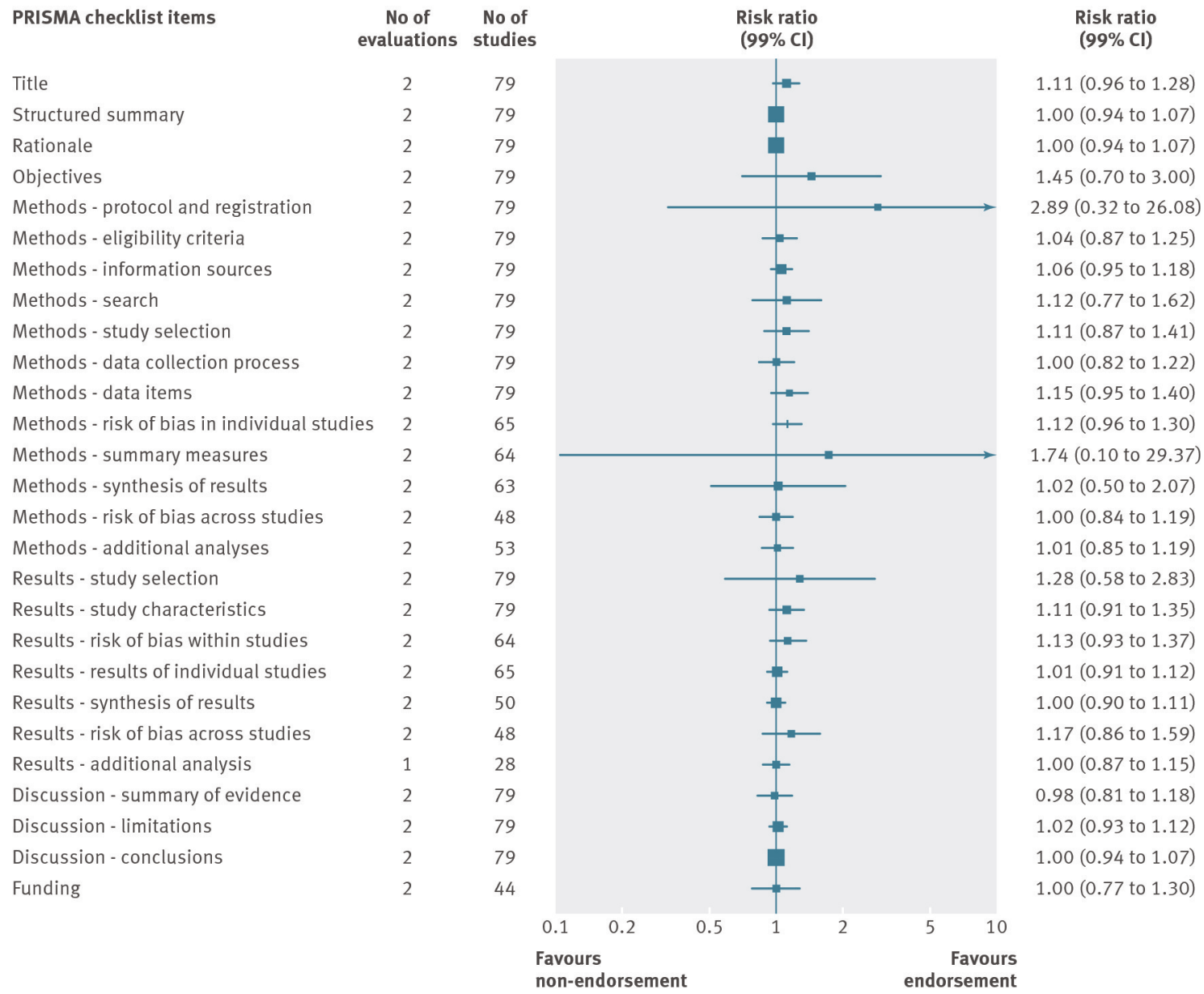

Fig 10 Completeness of reporting summary plot for PRISMA checklist, after versus before journal endorsement. Although all evaluations assessed all items, one evaluation was excluded from analysis of one checklist item because of zero and one studies for comparison arms

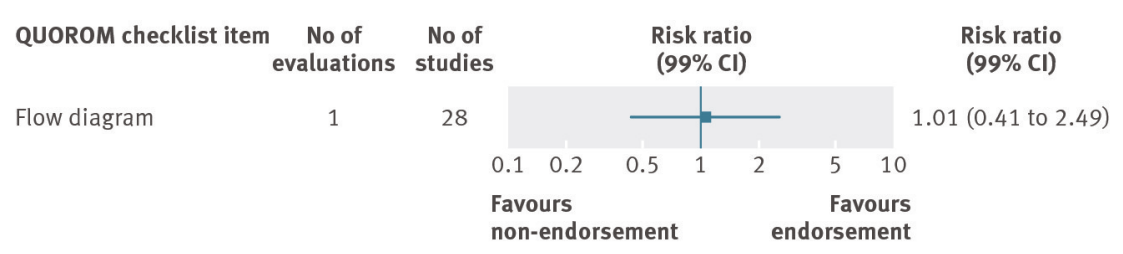

Fig 11 Completeness of reporting summary plot for QUOROM checklist, after versus before journal endorsement

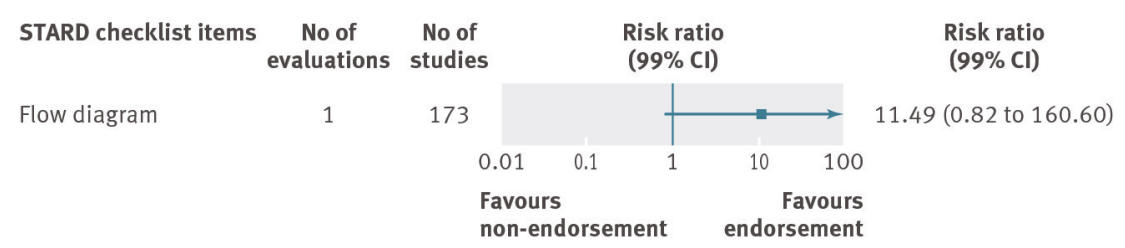

Fig 12 Completeness of reporting summary plot for STARD checklist, after versus before journal endorsement 


\section{STRICTA checklist items}

Style of acupuncture

Rationale for treatment

Sources to justify rationale

Points used (uni/bilateral)

Numbers of needles inserted

Depths of insertion

Responses elicited

Needle stimulation

Needle retention time

Needle type

Number of treatment sessions

Frequency of treatment

Duration of relevant training

Length of clinical experience

Expertise in specific condition

Explanations given regarding treatment and control 1

Sources that justify choice of control

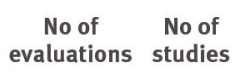

15
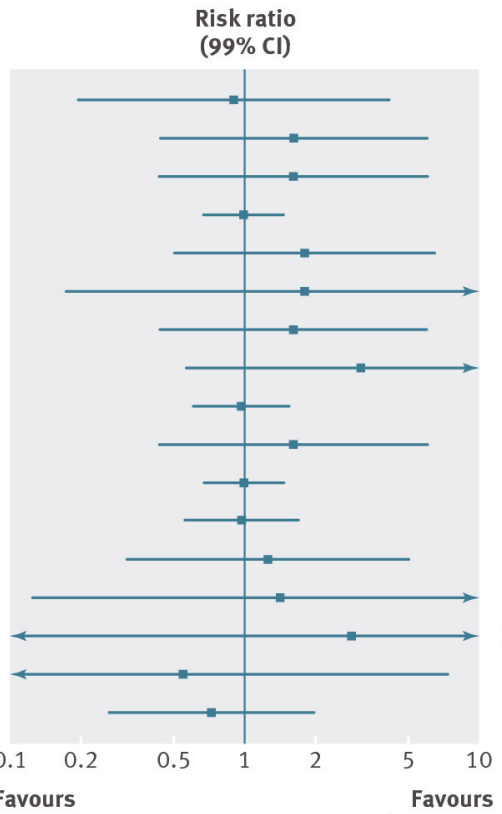

endorsem

Risk ratio

$(99 \% \mathrm{Cl})$

0.91 (0.19 to 4.31$)$

1.64 (0.43 to 6.25$)$

1.64 (0.43 to 6.25$)$

$1.00(0.66$ to 1.51$)$

$1.82(0.49$ to 6.75$)$

1.82 (0.17 to 19.64$)$

1.64 (0.43 to 6.25$)$

$3.19(0.55$ to 18.60$)$

0.97 (0.60 to 1.56$)$

$1.64(0.43$ to 6.25$)$

1.00 (0.66 to 1.51$)$

0.97 (0.54 to 1.75$)$

$1.27(0.31$ to 5.22$)$

1.45 (0.12 to 17.24$)$

2.92 (0.08 to 109.09$)$

0.55 (0.04 to 7.72$)$

$0.73(0.26$ to 2.04$)$

Favours

non-endorsement

Fig 13 Completeness of reporting summary plot for STRICTA checklist, after versus before journal endorsement 
STROBE checklist items

Title or abstract

Abstract

Introduction - background and rationale Introduction - objectives

Methods - study design

Methods - setting, location, dates

Methods - participant eligibility

Methods - participant matching

Methods - outcome, exposure, other variables

Methods - data sources and measurement

Methods - addressing sources of bias

Methods - study size

Methods - handling of quantitative variables

Methods - statistical methods

Methods - subgroups and interactions

Methods - loss to follow-up, matching, sampling

Methods - sensitivity analyses

Results - participant flow

Results - reasons for nonparticipation

Results - flow diagram

Results - participant characteristics

Results - missing data

Results - follow-up time (cohort studies)

Results - outcome data

Results - estimates and precision

Results - boundaries for continuous variable categories

Results - translating relative into absolute risk estimates

Results - other analyses

Discussion - key results

Discussion - limitations

Discussion - interpretation

Discussion - generalizability

Other - funding

$\begin{array}{cc}\text { No of } & \text { No of } \\ \text { evaluations } & \text { studies }\end{array}$

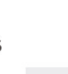
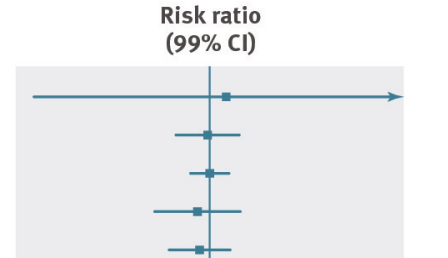

20

20

20

15

20

20

20

20

20

20

20

19

20

20

20

20

20

20

5

20

20

20

18

20

20

20

20

20

20
Risk ratio

( $99 \% \mathrm{Cl}$ )

1.22 (0.12 to 12.30$)$

0.98 (0.66 to 1.45$)$

1.00 (0.78 to 1.28$)$

0.86 (0.51 to 1.45$)$

0.89 (0.61 to 1.29$)$

1.83 (0.56 to 6.01)

0.89 ( 0.61 to 1.29 )

1.00 (0.38 to 2.62)

$0.76(0.31$ to 1.88$)$

0.98 (0.66 to 1.45 )

0.81 (0.11 to 6.13)

1.83 (0.56 to 6.01)

0.86 (0.51 to 1.45$)$

1.07 (0.55 to 2.08)

$4.89(0.35$ to 68.31$)$

0.74 (0.10 to 5.56)

2.44 ( 0.13 to 45.89$)$

1.09 (0.68 to 1.75$)$

3.60 (0.06 to 212.23)

6.00 (0.13 to 277.35$)$

1.63 ( 0.75 to 3.53 )

6.00 (0.13 to 277.35$)$

1.00 (0.44 to 2.28$)$

0.86 (0.51 to 1.45 )

0.68 (0.37 to 1.25$)$

0.41 (0.03 to 5.95$)$

0.41 (0.01 to 19.77)

$0.92(0.19$ to 4.48$)$

1.00 (0.78 to 1.28$)$

1.34 (0.80 to 2.24)

1.09 (0.78 to 1.53$)$

0.89 (0.61 to 1.29 )

1.40 (0.72 to 2.72 )

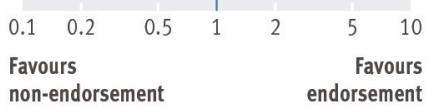

non-endorsement endorsement

Fig 14 Completeness of reporting summary plot for STROBE checklist, after versus before journal endorsement. Effect estimate for checklist item "Methods: missing data" was not estimable during quantitative analysis because of zero events in each arm 